\title{
10. RELATIONSHIP BETWEEN POROSITY, ELECTRICAL CONDUCTIVITY, AND CATION EXCHANGE CAPACITY IN BARBADOS WEDGE SEDIMENTS ${ }^{1}$
}

\author{
Pierre Henry ${ }^{2}$
}

\begin{abstract}
Measurements of grain densities in a shore-based laboratory show that the high dispersion of measurements obtained on board the JOIDES Resolution is probably related to insufficiently precise volumetric measurements, but that the effect of this imprecision on porosity determinations is generally less than $5 \%$. A correlation is found between the total water content of the samples and their cation exchange capacity (CEC). This correlation confirms that smectites strongly influence the ability of the sediment to retain both adsorbed and pore water. Chemical analysis show that (1) interlayer cations are dominantly $\mathrm{Na}$, (2) divalent cations ( $\mathrm{Mg}, \mathrm{Ca}$ ) take up to $30 \%-40 \%$ of the surface charge, and (3) $1 / 5$ to more than $1 / 3$ of the water present in the sample is chloride free. This chloride-free water corresponds to smectite interlayer water and to water adsorbed on external surfaces. Electrical resistivity logs as well as measurements on samples indicate a sharp decrease in resistivity in the transition from lithologic Units II to III. Lithologies with the highest smectite content (and highest CEC) have the lowest electrical conductivities at a given porosity. This result may in part be explained by water and ion adsorption in the smectite interlayer spaces but also leads to an unsolved question: Do 0.6-nm smectite interlayer spaces have the same conductance as the external surfaces of the particles?
\end{abstract}

\section{INTRODUCTION}

Porosity has been used extensively as an indicator of the effective stress supported by sediments in accretionary wedges (Bangs et al., 1990; Bray and Karig, 1985; Shi and Wang, 1988), and zones of abnormally high porosity of the sediment are interpreted as zones of high fluid pressure (Moore et al., 1995). This approach is supported by the general consistency of average compaction trends in marine sediments, but caution should be taken when different lithologies are encountered at a single location.

In the Ocean Drilling Program (ODP), porosities are usually derived from water content, and density measurements routinely made on board and referred to as index properties (IP). What is actually measured is a total water content, which includes the pore water as well as some of the intramineral water if hydrous minerals are present. In the Barbados wedge, some of the sediments from the offscraped sequence are very smectite rich (Tribble, 1990), and water present inside the clay particles as interlayer water cannot be neglected.

Alternatively, sediment electrical resistivity can be used as a porosity indicator, through empirical laws such as Archie's law (Archie, 1942), or through more complex models that include terms for the surface conductivity of the minerals (Clavier et al., 1977; de Lima and Sharma, 1990; Sen and Goode, 1988; Waxman and Smits, 1968). The surface conductivity terms may be dominant and can cause strong variations of porosity estimates depending on the mineralogy, notably for clay-rich sediments. In general, electrical resistivity increases when porosity decreases but data from the logging-whiledrilling (LWD) across the décollement zone at Site 948 follow the opposite trend (Fig. 1; Shipley, Ogawa, Blum, et al., 1995). This unusual behavior is investigated here.

'Shipley, T.H., Ogawa, Y., Blum, P., and Bahr, J.M. (Eds.), 1997. Proc. ODP, Sci. Results, 156: College Station, TX (Ocean Drilling Program)

${ }^{2}$ Ecole Normale Supérieure, Laboratoire de Géologie-CNRS URA 1316 \& URM 8, 24 Rue Lhomond, 75231 Paris Cedex 05, France. henry@sphene.ens.fr
A first objective of this study is to assess the quality of the porosity measurements made on board by comparing these with measurements made in a shore-based laboratory on a limited number of samples. A more fundamental problem is also to understand the meaning of porosity (or water content) data, as this parameter not only reflects the stress applied to the sample, but also the ability of the minerals to adsorb water on their external and internal surfaces. Large differences exist in the behavior of soil or sediment depending on the proportion of expandable clays, on the nature of the adsorbed cations, and on clay microstructure (Bruand and Prost, 1987; Meade, 1964; Tessier, 1991). Because there is no well-established law linking water retention with physical properties of minerals, this problem is often ignored in marine science. In this study, determinations of the cation exchange capacity, the exchangeable cation chemistry, and the electrical conductivity are used to extract information on the behavior of the clay surfaces and to estimate the in situ interlayer water content.

\section{MEASUREMENT PROCEDURES}

\section{Determination of Water Content and Grain Density}

The procedure used on board is summarized here, because it is presented in more detail elsewhere (Blum, 1994). The wet, saturated sample is weighed, and its volume measured in a helium pycnometer. After oven drying at $105^{\circ} \mathrm{C}$ for $24 \mathrm{hr}$, the sample is left to cool to room temperature in a desiccator, weighted, and its volume measured again. The bulk density $\rho$, grain density $\rho_{g}$ and porosity $\varphi$ are computed from the wet and dry masses ( $m_{w}$ and $m_{d}$ respectively) and one of the two volumetric measurements. In computing Method B, the wet volume $V_{w}$ is used, giving a direct measurement of bulk density, whereas in Method C, the dry volume $V_{d}$ is used, giving a direct measurement of the grain density $\rho_{g}$. A correction is applied for the salt precipitated during drying. Grain density is

$$
\rho_{g}=\frac{m_{d}-\left(m_{w}-m_{d}\right) \cdot S /(1-S)}{V_{w}-\left(m_{w}-m_{d}\right) /(1-S) \rho_{f}}
$$

with Method B, and 


$$
\rho_{g}=\frac{m_{d}-\left(m_{w}-m_{d}\right) \cdot S /(1-S)}{V_{d}-\left(m_{w}-m_{d}\right) \cdot S /(1-S) \rho_{s}}
$$

with Method C; $S$ is pore-fluid salinity (assumed 35\%o), $\rho_{f}$ is fluid density (assumed $1024 \mathrm{~kg} / \mathrm{m}^{3}$ ), and $\rho_{s}$ is salt density. Grain densities computed using Method B are systematically higher than grain densities computed using Method $\mathrm{C}$ by at least $0.1 \mathrm{~g} / \mathrm{cm}^{3}$, and the difference is sometimes more than $0.5 \mathrm{~g} / \mathrm{cm}^{3}$ (Shipboard Scientific Party, 1995). This error cannot be related to the salt correction, because this correction is much smaller. The balance was calibrated on board and the error in the measurements is less than $0.1 \%$. The reliability of the volume measurements is lower for several reasons. The reproducibility of the measurements is $\pm 0.02 \mathrm{~cm}^{3}$ at best $( \pm 0.25 \%)$. Larger systematic errors occur for samples significantly smaller than the standard $2 \times 2 \times 2 \mathrm{~cm}$ cubes cut on board, and although standards were run, the device was not calibrated during Leg 156.

Measurements were performed in a shore-based laboratory on samples from Hole 949B and 949D and on whole-round trimmings (Table 1). The procedure is identical except for the volume measurements. The wet volume was measured by weighing the samples in kerosene (density $0.870 \mathrm{~g} / \mathrm{cm}^{3}$; Monnier et al., 1973). The dry volume was not measured. As is standard in ODP, porosity here refers to the total volume occupied by water, without distinction between pore water and interlayer water.

\section{Cation Exchange Capacity and Determination of Exchangeable Cations}

All measurements where made at the Institut National de Recherche Agronomique (INRA) soil analysis laboratory at Arras. Cation exchange capacity (CEC) was measured by exchanging the cations with cobaltihexamine chloride (about $2 \mathrm{~g}$ material in $50 \mathrm{~mL}$ of 50 $\mathrm{mmol} / \mathrm{L}$ solution). This Method is standard and gives similar results as the ammonium acetate exchange method (Orsini and Remy, 1976). Major cations $\left(\mathrm{Na}^{+}, \mathrm{K}^{+}, \mathrm{Ca}^{2+}, \mathrm{Mg}^{2+}\right)$ are determined on the exchange solution by atomic emission or absorption. Standard error is about $1.5 \%$ on all determinations, corresponding to an uncertainty of $5 \%$ with a $99 \%$ probability. To obtain the true exchangeable cation composition, a correction must be applied for soluble salts. Soluble salts represent $0.15-0.3 \mathrm{eq} / \mathrm{kg}$ of the dry sample, whereas the CEC ranges from 0.24 to $1.03 \mathrm{eq} / \mathrm{kg}$. During the extraction, exchange of monovalent for divalent cations occur as predicted qualitatively by Donnan equilibrium (Murthy and Ferrell, 1972), which results in a very altered salt composition compared to the original pore fluid. For this reason, the chloride content determined by water extraction is used as a reference, and cation composition is computed assuming the composition of the salt is the same as that determined on board on interstitial water samples extracted from the same core. Errors may result from using different samples for the cation exchange and for the pore water. Soluble salts were extracted with the same solid water ratio as for the cation exchange ( $2 \mathrm{~g}$ for $50 \mathrm{~mL}$ ). To check that dissolution of chloride during the extraction was complete, total chloride contents were determined independently by a colorimetric method on 20 of the samples (samples were dissolved after alcaline fusion). Excluding two samples from a whole round that was particularly heterogenous (interval 156-949B-15X-5, 65-76 cm), there is no systematic difference between the two methods, and the standard deviation is $7 \%$ of the $\mathrm{Cl}$ determination. Finally, in all of the interlayer cation determinations retained here, the corrected total cation charge is within 0.04 eq $/ \mathrm{kg}(7 \%)$ of the cobaltihexamine CEC.

The cation exchange capacity and all other chemical determinations are given in meq per gram of sample air dried in normal laboratory conditions $\left(20^{\circ}-25^{\circ} \mathrm{C}\right.$, relative humidity $45 \%-70 \%$; Tables $2-$ 4). For water content measurements, dry weight refers to oven drying at $105^{\circ} \mathrm{C}$; a correction is therefore needed for consistency in the de-

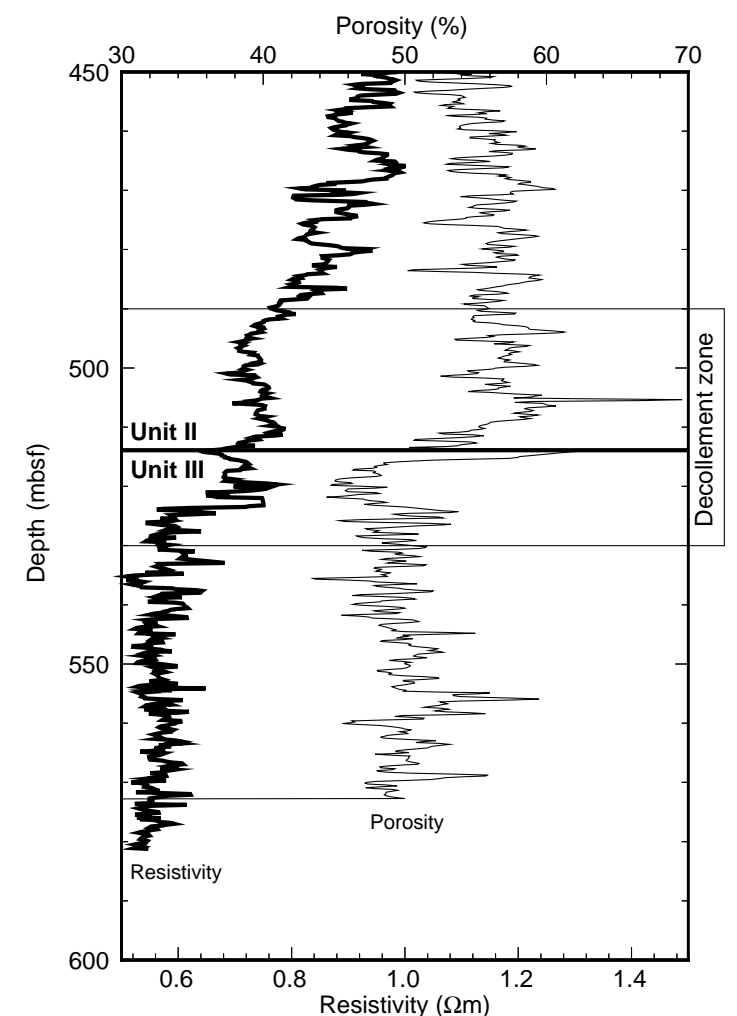

Figure 1. Porosity and uncorrected phase (shallow) resistivity from loggingwhile-drilling (LWD) at Site 948 in the interval around the décollement zone. The boundary between lithologic Units II and III is indicated.

termination of water distribution and of the number of adsorbed water molecules per cation charge. The water content after air drying at room temperature was determined by differential thermal analysis (DTA) on some of the samples (Table 3). For other samples, the water content after air drying at room temperature is computed from CEC using Equation 6 (see Results section).

\section{Electrical Conductivity Measurements}

Measurements made on board were properly calibrated only for Site 949, and the absolute conductivity values obtained at this site should still be taken with caution (Shipboard Scientific Party, 1995). Measurements were reproducible within about $10 \%$ and thus seem to be fairly reliable as relative measurements. In the shore-based laboratory, measurements were made on 2.5 -cm-diameter push cores taken from whole-round samples. The electrical impedance of the cylindrical sample held between two stainless steel electrodes was measured using a Hewlett-Packard 4284A component analyzer. Synthetic pore water (conductivity $4.7 \mathrm{~S} / \mathrm{m}$ at $17.5^{\circ} \mathrm{C}$ ) is used to obtain a good contact between electrodes and sample. Measurements are made at $100 \mathrm{~Hz}, 1 \mathrm{kHz}, 10 \mathrm{kHz}, 100 \mathrm{kHz}$ and $1 \mathrm{MHz}$. The measured imaginary component of the impedance is large at the lowest frequencies $(100 \mathrm{~Hz}$ and $1 \mathrm{KHz})$, but neglectable at $100 \mathrm{kHz}$, when compared to the real part. The imaginary term lacks in reproducibility and, unlike the real part, appeared to be independent of sample length, which leads us to suspect an electrode polarization problem. The electrical contact between cleaned electrodes, either dry or wet, is good. When electrodes are brought in contact immediately after a measurement on a sample, a nonzero impedance is measured, and its imaginary component is usually within $20 \%$ of the value measured with the sample 
Table 1. Density measurements and cation exchange capacity.

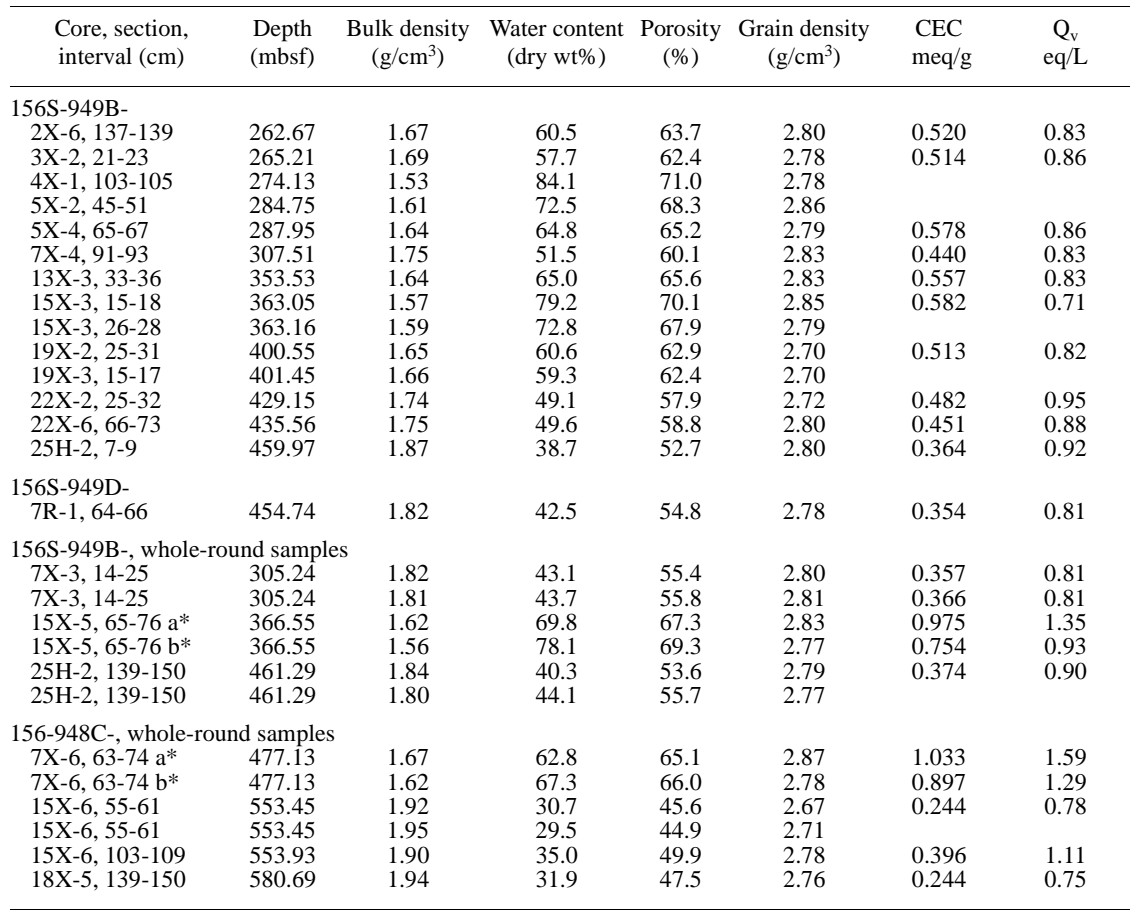

Notes: $\mathrm{CEC}=$ cation exchange capacity. $*=$ heterogeneous whole-round samples.

in place. The value obtained was interpreted as a contact impedance and subtracted from the measurement. Residual imaginary impedance component is not considered to be significant, and no dielectric constant has been determined. The reproducibility of the conductivity measurements is increased by this correction (down to $\pm 0.02 \mathrm{~S} / \mathrm{m}$ ). As checked by recutting one sample, the corrected conductivity showed little dependence on sample length. Measurements at $100 \mathrm{~Hz}$ were too strongly affected by the correction and are discarded. As the phase angle is minimal in the $10-\mathrm{kHz}$ to $100-\mathrm{kHz}$ range, I would recommend to use these relatively high frequencies when doing measurements on board. Also, it would be convenient to measure conductivity on the cubes cut for $P$-wave measurements and index properties by placing them between $2 \times 2 \mathrm{~cm}$ plate electrodes. A small amount of seawater is needed to obtain a reliable contact between the electrodes and the sample.

For measurements on board, conversion to apparent formation factor, $F=\sigma_{\text {sample }} / \sigma_{\text {fluid }}$, was made assuming a pore-fluid conductivity equal to that of standard seawater. For the shore-based measurement, the conductivity of the synthetic pore fluid is used.

\section{RESULTS: WATER CONTENT AND CATION EXCHANGE CAPACITY}

\section{Grain Density}

The raw water content measured on samples collected from Site 949 is comparable to that obtained on board (Fig. 2). Although only 15 samples were processed, they span the whole range of water contents and lithologies. There is no evidence for water loss during transportation. Grain densities obtained on these samples cluster around $2.8 \mathrm{~g} / \mathrm{cm}^{3}$, halfway between values obtained with Method B and Method C (Fig. 3). Samples from lithological Unit IIe (from 398.80 to $430.92 \mathrm{mbsf}$ ) have a lower grain density, possibly in relation with the presence of radiolarians (Shipley, Ogawa, Blum, et al., 1995). Abnormally high densities were measured on several samples, but bulk X-ray diffraction (XRD) analysis did not help to identify the cause of these high values.
The method used to measure the grain density on board appears imprecise, and most of the scatter is probably related to the volumetric measurement rather than to actual variations of the grain density. It may be a better choice in some cases to assume an average density than to measure it systematically on all samples. However, the consequences of a large error on the grain densities only has moderate effects on the computed porosities. Porosity, $\varphi$, is expressed as a function of wet and dry masses $\left(\mathrm{m}_{w}\right.$ and $\mathrm{m}_{d}$, respectively) and grain and fluid density

$$
\varphi=\frac{\left(m_{w}-m_{d}\right) /(1-S) \rho_{f}}{\left(m_{w}-m_{d}\right) /(1-S) \rho_{f}+\left[m_{d}-\left(m_{w}-m_{d}\right) \cdot S /(1-S)\right] / \rho_{g}}, \text { (3) }
$$

and the error on $\varphi$ resulting from an error on $\rho_{g}$ can be approximated as

$$
\Delta \varphi=\varphi(1-\varphi) \Delta \rho_{g} / \rho_{g} .
$$

Then, for example, varying the assumed grain density from 2.5 to 3 $\mathrm{g} / \mathrm{cm}^{3}$ changes the porosity by less than $4.5 \%$ at any porosity.

\section{Cation Exchange Capacity}

Cation exchange capacities (CEC; Tables 1-4; Fig. 4) were measured on sediment samples from Site 948 , and on whole-round trimmings from both Site 948 and Site 949. For Site 949, additional measurements were done on samples that had been squeezed on board for interstitial water extraction. These samples are referred to as interstitial water squeeze cakes (Table 4). At both sites, the CEC is higher in lithological Unit II than in lithological Unit III and follows the variations of smectite abundance (Underwood and Deng, Chapter 1, this volume). Typical CEC values are $0.3 \mathrm{eq} / \mathrm{kg}$ in Unit III and $0.6 \mathrm{eq} / \mathrm{kg}$ in Unit II, but CEC is more variable in Unit II than in Unit III and reaches $1 \mathrm{eq} / \mathrm{kg}$ in the most smectite-rich samples. At Site 949, the CEC variations with depth follow roughly the water content variations. The progressive decrease of the CEC from 480 to $530 \mathrm{mbsf}$ at Site 948 mimics the resistivity decrease observed over the same in- 
Table 2. Interlayer cation composition.

\begin{tabular}{|c|c|c|c|c|c|c|c|c|c|c|c|}
\hline \multirow{2}{*}{$\begin{array}{l}\text { Sediment sample: } \\
\text { core, section, } \\
\text { interval }(\mathrm{cm})\end{array}$} & \multirow{2}{*}{$\begin{array}{l}\text { I.W. sample: } \\
\text { core, section, } \\
\text { interval }(\mathrm{cm})\end{array}$} & \multicolumn{5}{|c|}{ Interstitial water composition $^{1}$} & \multirow{2}{*}{$\begin{array}{c}\begin{array}{c}\text { Soluble extract } \\
(\mathrm{meq} / 100 \mathrm{~g})\end{array} \\
\mathrm{Cl}\end{array}$} & \multicolumn{4}{|c|}{$\begin{array}{l}\text { Exchangeable cations (meq/100 g) } \\
\text { uncorrected data }\end{array}$} \\
\hline & & $\begin{array}{c}\mathrm{Cl} \\
(\mathrm{mM})\end{array}$ & $\begin{array}{c}2 \mathrm{Ca} / \mathrm{Cl} \\
(\%)\end{array}$ & $\begin{array}{c}2 \mathrm{Mg} / \mathrm{Cl} \\
(\%)\end{array}$ & $\begin{array}{c}\mathrm{K} / \mathrm{Cl} \\
(\%)\end{array}$ & $\begin{array}{c}\mathrm{Na} / \mathrm{Cl} \\
(\%)\end{array}$ & & $\mathrm{Ca}$ & $\mathrm{Mg}$ & $\mathrm{K}$ & $\mathrm{Na}$ \\
\hline \multicolumn{12}{|l|}{ 156-949B- } \\
\hline $2 X-6,137-139$ & $2 X-5,110-150$ & 547 & 14.1 & 11.5 & 0.77 & 79.7 & 24.1 & 13.5 & 8.7 & 4.7 & 51.1 \\
\hline $3 \mathrm{X}-2,21-23$ & $3 X-5,110-150$ & 545 & 14.0 & 11.6 & 0.75 & 79.6 & 23.0 & 13.4 & 8.8 & 4.6 & 49.9 \\
\hline $5 X-4,65-67$ & $5 \mathrm{X}-4,110-150$ & 535 & 14.2 & 11.4 & 0.73 & 79.6 & 20.4 & 16.3 & 9.6 & 4.1 & 52.6 \\
\hline $7 X-4,91-93$ & $7 X-2,110-150$ & 563 & 13.4 & 9.8 & 0.87 & 82.2 & 19.4 & 13.5 & 8.1 & 3.3 & 41.5 \\
\hline $13 X-3,33-36$ & $13 \mathrm{X}-1,110-150$ & 544 & 14.3 & 10.9 & 0.79 & 80.0 & 23.3 & 16.6 & 7.3 & 4.8 & 56.0 \\
\hline $15 X-3,15-18$ & $15 \mathrm{X}-2,110-150$ & 541 & 14.9 & 11.2 & 0.74 & 79.3 & 23.9 & 16.4 & 9.9 & 4.5 & 54.9 \\
\hline $19 X-2,25-31$ & $19 \mathrm{X}-2,60-100$ & 532 & 14.5 & 12.9 & 0.73 & 77.8 & 22.5 & 14.2 & 11.0 & 2.0 & 47.5 \\
\hline $22 X-2,25-32$ & $22 X-5,110-150$ & 540 & 14.0 & 12.0 & 0.72 & 79.1 & 19.6 & 13.4 & 9.7 & 2.4 & 43.8 \\
\hline $22 X-6,66-73$ & $22 \mathrm{X}-5,110-150$ & 540 & 14.0 & 12.0 & 0.72 & 79.1 & 16.0 & 13.8 & 7.0 & 3.3 & 39.4 \\
\hline $25 \mathrm{H}-2,7-9$ & $25 \mathrm{H}-3,110-150$ & 559 & 14.9 & 12.9 & 0.59 & 76.6 & 15.8 & 11.7 & 5.5 & 3.4 & 33.1 \\
\hline $\begin{array}{l}\text { 156-949C- } \\
\text { 7R-1, 64-66 }\end{array}$ & $7 \mathrm{R}-1,80-90^{2}$ & 563 & 14.2 & 12.5 & 0.59 & 76.6 & 17.9 & 11.3 & 6.5 & 3.4 & 34.4 \\
\hline Seawater reference & $1 \mathrm{H}-1,143-150$ & 559 & 4.0 & 18.4 & 1.95 & 86.2 & & & & & \\
\hline
\end{tabular}

Notes: I.W. = interstitial water.

${ }^{1}$ Shipboard determination.

${ }^{2} \mathrm{~K} / \mathrm{Cl}$ and $\mathrm{Na} / \mathrm{Cl}$ assumed.

terval with the LWD (Fig. 1). The observation that resistivity decreases over an interval where both porosity and cation exchange capacity decrease is unusual will be the subject of the discussion section.

\section{Exchangeable Cation Composition}

Interlayer cation compositions were only determined at Site 949 (Tables 2-5). They are fairly constant over the cored interval (Fig. 5). The interstitial fluid contains much more calcium ( 3 to 4 times more) than seawater, about half less magnesium, about a third potassium, and slightly less sodium. When comparing with typical values for smectites in equilibrium with seawater (Sayles and Mangelsdorf, 1977), the change in $\mathrm{Ca} / \mathrm{Mg}$ value of the pore fluid is reflected in the exchangeable cation composition. The proportion of potassium among exchangeable cations is larger than that expected for a pure smectite and may be explained by a contribution of illite to the CEC. In average, $60 \%$ of the charge is compensated by $\mathrm{Na}^{+}, 3 \%-10 \%$ by $\mathrm{K}^{+}, 8 \%-15 \%$ by $\mathrm{Mg}^{2+}$, and $20 \%-25 \%$ by $\mathrm{Ca}^{2+}$. This makes predictions of the hydration state uncertain, but the behavior of the smectite should be closer to that of a sodium smectite. A sodium smectite typically retains one layer of water after air drying (under $50 \%$ water vapor saturation). One layer of water corresponds to a $1.3 \mathrm{~nm}(001)$ spacing, to a water content of about $10 \%$ dry weight, and to 2-2.5 water molecules per unit formula $(\mathrm{Si}, \mathrm{Al})_{4} \mathrm{O}_{10}$ (Bird, 1984; Keren and Shainberg, 1975; Ransom and Helgeson, 1995). Calcium smectites under the same conditions have a 1.5- to 1.6-nm layer spacing and contain about $20 \%$ dry weight water, or 4.5 water molecules per unit formula. When in low ionic strength water (less than $0.3 \mathrm{NaCl}$ ), smectites, especially when the interlayer cation is $\mathrm{Na}$, form gels and retain much larger amounts of water in the interlayer spaces. This equilibrium state depends on the temperature, the ionic force of the fluid, and the applied effective pressure. For a fluid at room temperature that has the ionic strength of seawater, the layer spacing collapses to 2 or 3 water layers (1.6 or $1.9 \mathrm{~nm}$ spacing; Meade, 1964). A particular property of Na-smectites is an ability to regain equilibrium water content regardless of past effective stresses, whereas smectites with divalent interlayer cations have a very partial recovery (Tessier, 1991). This has obvious implications for the behavior during tectonic unloading, especially if the unloading is attributed to the effect of fluid injections.

\section{Relationship Between Water Content and Cation Exchange Capacity}

The total water content ( $w$, in percent of dry weight) and the CEC (in eq/kg) are strongly correlated. For samples at Site 949 (Fig.6) with CEC in the range $0.3-0.6 \mathrm{eq} / \mathrm{kg}$,

$$
w=(116.53) \times \mathrm{CEC}-(1.62), \mathrm{R}^{2}=0.92 .
$$

This correlation fails for samples having a CEC higher than 0.6 eq $/ \mathrm{kg}$. Total water content then decreases with increasing CEC. The samples cored from Site 949 were presumably subject to a low preconsolidation stress, ranging from 200 to $700 \mathrm{kPa}$ (Brückmann et al., Chapter 7 , this volume). Although they presumably experienced a higher level of stress, whole-round samples from Site 949 apparently follow the same trend, but data are too few to reach a definite conclusion. These results cast doubts about the possible identification of zones of high pore pressures from porosity measurements only. Indeed, consolidation tests on samples from Barbados wedge that were collected during Legs 156 and 110 show a large dispersion of the initial water content for a given preconsolidation stress (Taylor and Leonard, 1990). Furthermore, preconsolidation stresses determined on samples from Hole 949B decrease with depth between Cores 156949B-15X (336 mbsf) and 22X (428.75 mbsf), following a trend opposite to that of porosity over the same depth interval (Brückmann et al., Chapter 7, this volume).

Several approaches have been tried to estimate the water retention properties of the samples. Differential thermal analysis (DTA) curves were obtained from samples from Site 949 after air drying under $50 \%-70 \%$ water vapor saturation. As is usually obtained (Grim, 1953), adsorbed water is removed between room temperature and $300^{\circ} \mathrm{C}$, but most of it is removed before $110^{\circ} \mathrm{C}$ is reached. In the curves obtained from the Barbados samples, the water fraction removed between $110^{\circ}$ and $300^{\circ} \mathrm{C}$ represents only $2 \%$ of the dry weight. The adsorbed water content after air drying $\left(w_{a}\right)$ has been estimated from the weight loss between room temperature and $200^{\circ} \mathrm{C}$. Values are correlated with CEC by

$$
w_{a}=(13.04) \times \mathrm{CEC}+(1.78), \mathrm{R}^{2}=0.77 \text {. }
$$

This correlation is an indication that most water is adsorbed at smectite interlayer sites. 
Table 3. Interlayer cation, CEC, and water retention.

\begin{tabular}{|c|c|c|c|c|c|c|c|c|c|c|c|c|c|}
\hline \multirow{3}{*}{$\begin{array}{l}\text { Sediment sample: } \\
\text { core, section, } \\
\text { interval }(\mathrm{cm})\end{array}$} & \multirow{2}{*}{\multicolumn{5}{|c|}{$\begin{array}{l}\text { Exchangeable cations (meq/100 g) } \\
\text { salt-corrected }\end{array}$}} & \multirow{3}{*}{$\begin{array}{c}\text { Cobaltihexamine CEC } \\
(\mathrm{meq} / 100 \mathrm{~g})\end{array}$} & \multicolumn{4}{|c|}{ Original water content (dry wt\%) } & \multicolumn{3}{|c|}{ Air dried samples } \\
\hline & & & & & & & \multirow[b]{2}{*}{ Total } & \multirow[b]{2}{*}{ Pore } & \multicolumn{2}{|c|}{$\mathrm{Cl}$ free (bound) } & \multirow{2}{*}{$\begin{array}{c}\text { Vapor } \\
\text { saturation }\end{array}$} & \multicolumn{2}{|c|}{ Weight loss at $200^{\circ} \mathrm{C}$} \\
\hline & $\mathrm{Ca}$ & $\mathrm{Mg}$ & $\mathrm{K}$ & $\mathrm{Na}$ & $\Sigma$ Charges & & & & $\%$ & $\mathrm{H}_{2} \mathrm{O} /$ charge & & $\%$ & $\mathrm{H}_{2} \mathrm{O} /$ charge \\
\hline \multicolumn{14}{|l|}{ 156-949B- } \\
\hline $2 X-6,137-139$ & 10.1 & 5.9 & 4.6 & 31.9 & 52.5 & 52.0 & 60.5 & 46.9 & 13.6 & 15.7 & $47 \%$ & 7.8 & 7.7 \\
\hline $3 \mathrm{X}-2,21-23$ & 10.2 & 6.2 & 4.4 & 31.6 & 52.4 & 51.4 & 57.7 & 45.4 & 12.3 & 14.5 & & 8.7 & 8.6 \\
\hline $5 X-4,65-67$ & 13.3 & 7.2 & 4.0 & 36.3 & 60.9 & 57.8 & 64.8 & 41.1 & 23.7 & 24.8 & & 8.9 & 7.9 \\
\hline $7 X-4,91-93$ & 10.9 & 6.2 & 3.1 & 25.5 & 45.7 & 44.0 & 51.5 & 36.8 & 14.7 & 20.1 & $70 \%$ & 7.9 & 9.2 \\
\hline $13 X-3,33-36$ & 13.3 & 4.7 & 4.6 & 37.4 & 59.9 & 55.7 & 65.0 & 45.9 & 19.1 & 20.7 & $47 \%$ & 8.6 & 7.9 \\
\hline $15 X-3,15-18$ & 12.8 & 7.2 & 4.3 & 35.9 & 60.3 & 58.2 & 79.2 & 48.0 & 31.2 & 32.7 & $55 \%$ & 9.8 & 8.5 \\
\hline $19 \mathrm{X}-2,25-31$ & 10.9 & 8.1 & 1.9 & 30.0 & 50.9 & 51.3 & 60.6 & 45.8 & 14.8 & 17.6 & $52 \%$ & 9.6 & 9.5 \\
\hline $22 \mathrm{X}-2,25-32$ & 10.7 & 7.3 & 2.3 & 28.3 & 48.5 & 48.2 & 49.1 & 38.8 & 10.3 & 12.8 & $61 \%$ & 8.1 & 8.6 \\
\hline $22 X-6,66-73$ & 11.5 & 5.1 & 3.1 & 26.7 & 46.5 & 45.1 & 49.6 & 31.5 & 18.1 & 24.0 & $47 \%$ & 7.3 & 8.4 \\
\hline $25 \mathrm{H}-2,7-9$ & 9.3 & 3.4 & 3.3 & 21.0 & 37.1 & 36.4 & 38.7 & 29.8 & 8.9 & 14.5 & $63 \%$ & 6.8 & 9.8 \\
\hline \multirow{2}{*}{$\begin{array}{l}\text { 156-949C- } \\
\text { 7R-1, 64-66 }\end{array}$} & & & & & & & & & & & & & \\
\hline & 8.8 & 4.3 & 3.3 & 20.7 & 37.1 & 35.4 & 42.5 & 33.3 & 9.2 & 15.3 & $47 \%$ & 5.9 & 8.8 \\
\hline
\end{tabular}

Table 4. Cation exchange capacity and water retention.

\begin{tabular}{|c|c|c|c|c|c|c|c|c|c|}
\hline \multirow{3}{*}{$\begin{array}{l}\text { Sediment sample: } \\
\text { core, section, } \\
\text { interval }(\mathrm{cm})\end{array}$} & \multirow{3}{*}{$\begin{array}{l}\text { Depth } \\
\text { (mbsf) }\end{array}$} & \multirow{3}{*}{$\begin{array}{l}\text { I.W. sample: } \\
\text { core, section, } \\
\text { interval }(\mathrm{cm})\end{array}$} & \multirow{3}{*}{$\begin{array}{l}\text { I.W. } \\
\mathrm{Cl}^{2} \\
(\mathrm{mM})\end{array}$} & \multirow{3}{*}{$\begin{array}{l}\text { Soluble extract } \\
\text { Cl } \\
\text { (meq/100 g) }\end{array}$} & \multirow{3}{*}{$\begin{array}{c}\text { Cobaltihexamine } \\
\text { CEC } \\
\text { (meq/100 g) }\end{array}$} & \multicolumn{4}{|c|}{$\begin{array}{l}\text { Original water content } \\
(\text { dry wt } \%)\end{array}$} \\
\hline & & & & & & \multirow[b]{2}{*}{ Total } & \multirow[b]{2}{*}{ Pore } & \multicolumn{2}{|c|}{$\mathrm{Cl}$ free (bound) } \\
\hline & & & & & & & & $\%$ & $\mathrm{H}_{2} \mathrm{O} /$ charge \\
\hline \multicolumn{10}{|c|}{ 156-948C interstitial water squeeze cakes } \\
\hline $7 X-6,120-150$ & 477.8 & Same sample & 511 & 15.5 & 72.7 & 45.1 & 33.4 & 14.8 & 12.6 \\
\hline $8 X-3,110-150$ & 483.0 & Same sample & 512 & 11.8 & 64.2 & 36.2 & 25.2 & 13.1 & 12.5 \\
\hline $9 X-4,115-150$ & 494.2 & Same sample & 461 & 14.4 & 72.0 & 45.6 & 34.3 & 14.4 & 12.3 \\
\hline $10 X-3,110-150$ & 502.4 & Same sample & 511 & 13.1 & 54.3 & 38.1 & 27.7 & 12.4 & 13.8 \\
\hline $11 X-3,120-150$ & 512.1 & Same sample & 538 & 12.6 & 49.4 & 34.2 & 25.1 & 10.7 & 13.0 \\
\hline $12 X-4,110-150$ & 523.2 & Same sample & 564 & 15.2 & 42.1 & 36.9 & 28.5 & 10.0 & 14.1 \\
\hline $13 X-4,115-150$ & 532.6 & Same sample & 571 & 13.1 & 31.1 & 31.6 & 24.0 & 8.7 & 16.4 \\
\hline $15 X-6,110-150$ & 554.2 & Same sample & 560 & 13.3 & 35.3 & 35.1 & 24.9 & 11.5 & 19.2 \\
\hline \multicolumn{10}{|c|}{$156-948 \mathrm{C}$ whole-round samples } \\
\hline $7 X-6,63-74 \mathrm{a}^{1}$ & 477.13 & $7 X-6,120-150$ & 511 & 17.0 & 103.3 & 62.8 & 37.9 & 25.0 & 15.5 \\
\hline $7 X-6,63-74 b^{1}$ & 477.13 & $7 X-6,120-150$ & 511 & 23.4 & 89.7 & 67.3 & 51.4 & 15.8 & 11.1 \\
\hline $15 X-6,55-61$ & 553.45 & $15 X-6,110-150$ & 560 & 13.0 & 24.4 & 29.5 & 24.1 & 5.4 & 12.9 \\
\hline $15 X-6,103-109$ & 553.93 & $15 X-6,110-150$ & 560 & 14.6 & 39.6 & 35.0 & 27.6 & 7.4 & 11.1 \\
\hline $18 X-5,139-150$ & 580.69 & $18 \mathrm{X}-4,110-150$ & 554 & 14.6 & 24.4 & 31.9 & 27.2 & 4.7 & 11.2 \\
\hline \multicolumn{10}{|c|}{ 156-949B whole-round samples } \\
\hline $7 X-3,14-25$ & 305.24 & $7 X-2,110-150$ & 563 & 17.8 & 35.7 & 43.1 & 33.2 & 9.9 & 16.3 \\
\hline $7 X-3,14-25$ & 305.24 & $7 X-2,110-150$ & 563 & 17.6 & 36.6 & 43.7 & 32.8 & 10.9 & 17.6 \\
\hline $15 X-5,65-76 \mathrm{a}^{1}$ & 366.55 & $15 X-5,110-150$ & 538 & 24.2 & 97.5 & 69.8 & 51.0 & 18.8 & 12.3 \\
\hline $15 X-5,65-76 b^{1}$ & 366.55 & $15 X-5,110-150$ & 538 & 30.0 & 75.4 & 78.1 & 61.6 & 16.5 & 13.5 \\
\hline $25 \mathrm{H}-2,139-150$ & 461.29 & $25 \mathrm{H}-3,110-150$ & 559 & 15.6 & 37.4 & 40.3 & 29.4 & 10.9 & 17.2 \\
\hline
\end{tabular}

Notes: I.W. = interstitial water.

${ }^{1}$ Heterogeneous whole-round samples.

${ }^{2}$ Shipboard determination.

Another way to interpret these data is to compute the number of water molecules per cation charge. For an ideal smectite having a layer charge between 0.3 and 0.4 , the expected number of water molecules per charge are $6-8,12-16$, and $18-24$ for one, two, and three water layers, respectively. The number of water molecules per cation charge consistently lies between 7.7 and 9.8 in all samples, which could indicate either that one water layer is retained in smectites with $1.8 \mathrm{wt} \%$ water adsorbed on uncharged surfaces, such as fine-grained kaolinite, or that these smectites have a behavior intermediate between a typical $\mathrm{Na}$ and a typical $\mathrm{Ca}$ or $\mathrm{Mg}$ smectite.

The proportion of true interstitial water in the saturated samples is estimated from the total water content and the chloride content in the extract. As shown earlier, all the chloride salts are dissolved during the extraction by dilution in deionized water. Anions are excluded from the interlayer of smectites and, according to the double layer theory, from a thin layer around external positively charged surfaces. The thickness of this layer decreases with salinity up to a critical concentration when all counter-ions are concentrated in a single layer of hydrated cations, the Helmholtz layer. The thickness of the Helmholtz layer is about $0.6 \mathrm{~nm}$, and the critical concentration is reached for a salinity only slightly higher than that of seawater (Clavier et al.,
1977; Pride, 1994; Revil and Glover, 1997). The thickness of the double layer is thus comparable, in seawater, to the smectite interlayer spacing. It is possible to schematically split the total water content of the sample in a fraction that contains the same chloride concentration as the pore water and a fraction that is totally chloride free (Fig. 7). This chloride-free part represent interlayer water, and water in the double layer. This method thus gives a reasonable upper bound to total adsorbed water.

As shown on Figure 6B, pore water determined by this method appears to be less variable and less correlated with CEC than total water content. Except for one anomalous sample, the chloride-free water content ranges from 5 to $25 \mathrm{wt} \%$, and the number of water molecules per cation charge ranges from 11 to 25 . Assuming most of the chloride-free water lies in smectite interlayers, these values are compatible with 2 or 3 water layers, depending on the samples (Tables 2-4; Fig. 8). Samples from Site 948 (whole rounds and squeeze cakes) apparently retain fewer water molecules per cation charge than samples from Site 949. This may indicate that a fraction of the adsorbed water is expelled during natural compaction and/or squeezing. Regardless of the model for water adsorption, it is important for chemical budgets to note that between $1 / 6$ and $1 / 3$ of all the water present in the sam- 


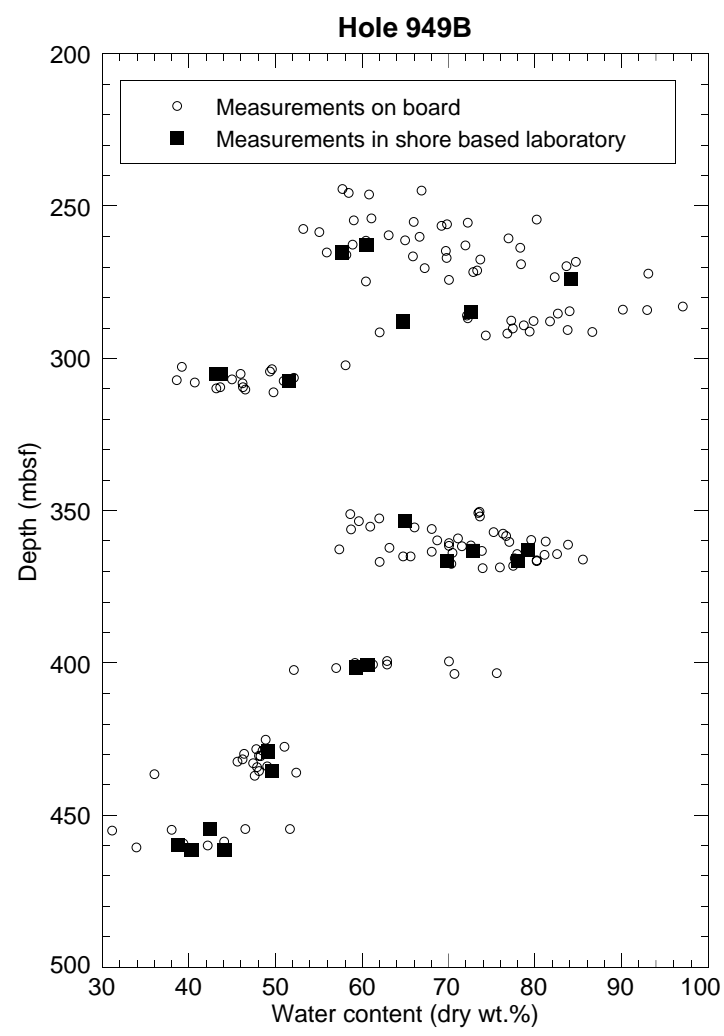

Figure 2. Comparison of water contents measured on board and after the cruise. There is no evidence for water loss during transport.

ples is chloride free, and that this water is expected to be released continuously as temperature and effective pressure increases, even if no recrystallization occurs (Bird, 1984; Colten-Bradley, 1987; Ransom and Helgeson, 1995).

\section{RESULTS: ELECTRICAL CONDUCTIVITY}

\section{Site 948 LWD Data}

For comparison with laboratory measurements, resistivity measurements from LWD must be corrected for temperature variations with depth (Von Herzen et al., 1983). There is evidence that the activation energy is higher for surface conduction than for conduction in seawater, which implies that surface conduction becomes more important when temperature increases (Olhoeft, 1981; Pezard, 1990), but there is no well-established law for marine sediments. In the case of Site 948, the high porosity of the sediments and the moderate temperature range $\left(0^{\circ}-40^{\circ} \mathrm{C}\right)$ justify computation of an approximate correction based on the variation of seawater conductivity $\sigma_{0}$ with temperature as follows:

$$
\sigma_{0}=2.8+0.1 \mathrm{~T}\left({ }^{\circ} \mathrm{C}\right) \Omega^{-1} \mathrm{~m}^{-1} .
$$

The same linear approximation was used for the correction of measurements on board (Shipboard Scientific Party, 1995). Temperatures are computed by linear interpolation between bottom-hole temperature measurements (with WSTP probe), and extrapolated assuming a constant gradient of $66^{\circ} \mathrm{C} / \mathrm{km}$ below $420.5 \mathrm{mbsf}$.

To convert the LWD gamma-ray densitometry data into porosity, the grain density is assumed at $2.8 \mathrm{~g} / \mathrm{cm}^{3}$, except in the zone from 490

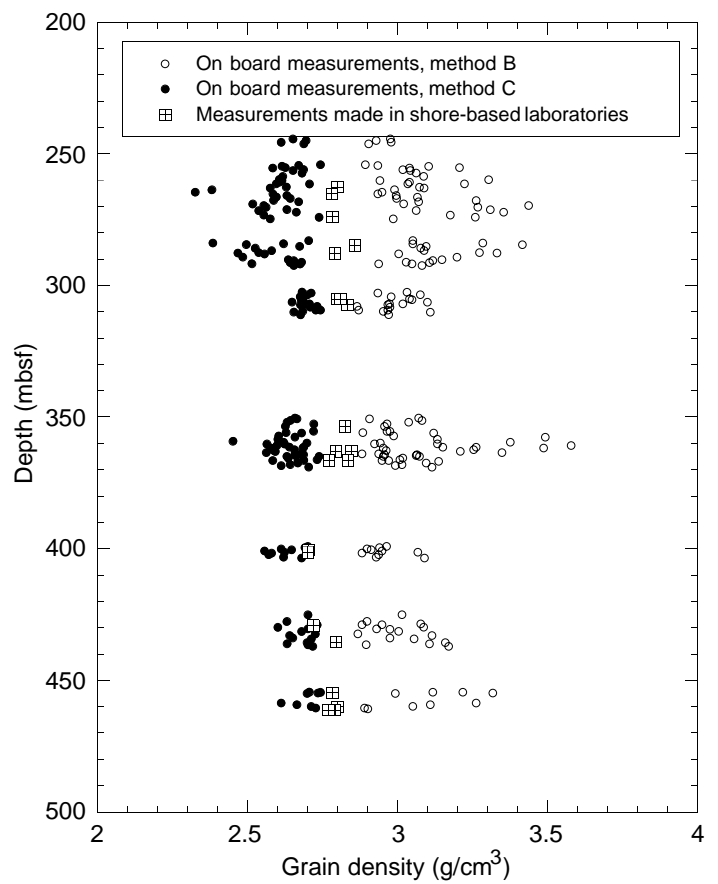

Figure 3. Comparison of grain density measurements made on board and in a shore-based laboratory.

to $500 \mathrm{mbsf}$ at Site 948 , which corresponds to the radiolarian-bearing Unit IIe. For this unit, a grain density of $2.71 \mathrm{~g} / \mathrm{cm}^{3}$ is assumed.

The resistivity vs. porosity cross-plot of all LWD data from Hole 948A shows two distinct populations (Fig. 9). The main, elongated, cluster corresponds to all lithologies from the surface to the décollement. The cluster of lower resistivity points corresponds to the underthrust sequence (Unit III). The lithological boundary thus appears as a major change in electrical conductivity. Looking more closely at the data, a bump of higher resistivities in the main cloud for porosities of $50 \%-60 \%$ corresponds to data from the high porosity interval within Unit II. Four LWD zones are defined. Zone 1 corresponds to the first thrust packet, down to $130 \mathrm{mbsf}$. Zone 2 correspond to the upper part of the thrust packet down to the top of the low-porosity zone at $400 \mathrm{mbsf}$. Zone 3 corresponds to the high-porosity zone between 400 and $515 \mathrm{mbsf}$. Zone 4 corresponds to the underthrust material and to lithological Unit III.

The next step is to correct for variations in pore-fluid conductivity caused by fluid composition. Two synthetic pore-fluid samples were prepared. One corresponds to the average composition of interstitial water samples. The other corresponds to interval 156-948C-7X-6, $120-150 \mathrm{~cm}$. With a chlorinity of $511 \mathrm{mM}$, it can be considered typical of the high-porosity zone. The average fluid has a chlorinity of $553 \mathrm{mM}$ and a conductivity of $4.68 \pm 0.2 \Omega^{-1} \mathrm{~m}^{-1}$ at $17.5^{\circ} \mathrm{C}$, comparable to that of seawater at the same temperature $\left(4.55 \Omega^{-1} \mathrm{~m}^{-1}\right)$. The conductivity of the lower chlorinity fluid is $4.3 \pm 0.2 \Omega^{-1} \mathrm{~m}^{-1}$. The conductivity difference is thus $8.8 \%$, whereas the chlorinity difference is $8.2 \%$. In view of this result and considering that sodium chloride is the main contributor to conductivity in seawater, an approximate correction is applied assuming that fluid conductivity is proportional to chlorinity. Chlorinity is interpolated from a compilation of Sites 671 and 948 data. Other variations of fluid chemistry are ignored here.

The apparent formation factor $(F)$ is defined as the ratio of the temperature corrected resistivity to the assumed fluid conductivity. This formation factor is of convenient use for data comparison, but is not tied to a physical model of porous medium because surface conductivity is not taken into account at this stage. 

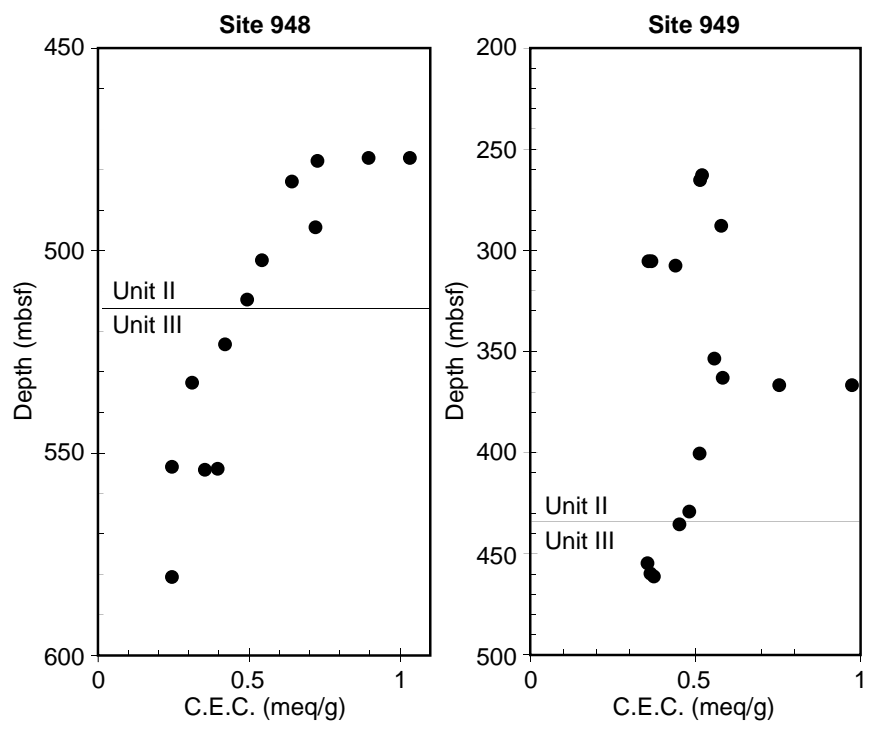

Figure 4. Cation exchange capacity determined on sediment samples by cobaltihexamine $\left(\mathrm{Co}\left(\mathrm{NH}_{3}\right)_{6}\right)^{3+}$ substitution.

The sharp contrast in resistivity between the offscraped units (lithological Units I and II) and the underthrust unit (lithological Unit III) is still observed after the salinity correction (Fig. 10). For the purpose of figure legibility, logging data are averaged for each 5-m interval. A sliding average method is applied, using a Gaussian curve of 5-m half-width for weighting. Data from all of Units I and II define a trend that can be fit by a power law,

$$
\mathrm{F}=1.24 \varphi^{-2.31}, \mathrm{R}=0.96
$$

This fit is in the range considered typical for marine sediments (Iversen and Jørgensen, 1993; Manheim and Waterman, 1974). The high-porosity zone within Unit II plots close to the main trend after the salinity correction. This suggests that its anomalous behavior is mostly due to the lower salinity of the pore fluid, but the uncertainty on the temperature correction does not allow for a firm conclusion.

\section{Measurements on Samples}

Conductivity measurements made on board as well as measurements made in the shore-based laboratory (tab 5) were converted to apparent formation factor $(F)$, assuming a conductivity equal to that of seawater for the pore fluid. Measurements made on board indicate that the most smectite-rich units (lithological Units IIc and IIe) have an anomalously high resistivity considering their water content (Fig. 11). These high-porosity, high-resistivity zones are from the same cores as the samples with CEC higher than $0.5 \mathrm{eq} / \mathrm{kg}$ (Cores 156-949C-2X through 5X, 13X through 15X, and 19X). Variations in salinity of the pore fluid is here an unlikely explanation, because the chlorinity of interstitial water varies by $5 \%$ maximum at Site 949 . The calcareous mud from Unit IIb typically has a lower resistivity. A high dispersion is observed in samples from lithological Unit III.

Whole-round samples span a wide range of CEC from $0.23 \mathrm{eq} / \mathrm{kg}$ to more than $1 \mathrm{eq} / \mathrm{kg}$ (Tables 2-4). Quantitative XRD analysis of the clay fraction is only available for three of the whole-round samples. Interval 156-949B-15X-5, 65-76 cm, from Unit IIc, has a very high smectite content in the clay fraction (more than 90\%), and corresponds to one of the benthonite-like layers reported by Underwood and Deng (Chapter 1, this volume). Interval 156-948C-7X-6, 63-74 $\mathrm{cm}$, also has a CEC close to $1 \mathrm{eq} / \mathrm{kg}$ and is probably similar. Both samples are heterogenous. The whitish benthonite is interlayered with a darker claystone that contains some kaolinite and quartz (from qualitative XRD) and has a lower CEC. These samples have a very high water content (69\% and 66\%, respectively), but once a correction for adsorbed water content is applied, the true porosity of these samples (49\% and 39\%, respectively) is comparable with that of the other samples. Section 156-949B-7X-3, from Unit IIb, has only about $30 \%$ smectites in the clay fraction, and interval 156-948C-18X-5, $139-150 \mathrm{~cm}$, from Unit III, has less than $20 \%$ smectites in the clay fraction. These results are consistent with the CEC determinations. Although dispersed, the conductivity measurements confirm that the smectite-rich samples from Unit IIc have an anomalously high resistivity for their water content (Table 5; Fig. 12). Unfortunately, these two samples are probably too smectite rich to be representative of the bulk of Unit IIc.

Measurements made on board using a Wenner 4-needles array did not show a significant conductivity difference depending on the orientation of the array with respect to bedding. Anisotropy could only be tested on two of the whole-round samples, and the horizontal and vertical measurements are indeed very close considering the precision of the measurements. The lack of evidence for sample scale anisotropy of course does not exclude formation scale anisotropy in a heterogeneous bedded formation such as lithological Unit III.

\section{Comparison with LWD}

Although the conductivity contrast between the zones immediately above and below the lithological boundary is shown both by LWD and measurements on samples, LWD resistivities are systematically lower in the deeper part, although they fit for the mudline cores. Measurements made on board may be higher than shore-based measurements because of difficulties to obtain a reliable electrical contact between the electrode array used on board and the sediment, but this should not apply when comparing shore-based measurements and LWD. Although the frequency range is different $(1-100 \mathrm{kHz}$ for the laboratory measurements vs. $2 \mathrm{MHz}$ for the LWD), frequency dependence of conductivity is not a likely explanation because laboratory measurements showed that the variation of conductivity with frequency is moderate ( $15 \%$ maximum between $1 \mathrm{kHz}$ and $100 \mathrm{kHz})$. As frequency dependence of conductivity in sediment is likely to be related to polarization effects in the diffuse boundary layer (de Lima and Sharma, 1992), the effects should be small in seawater. Furthermore, the good agreement between the phase and attenuation resistivity measurements indicates that at $2 \mathrm{MHz}$, polarization effects are too small to alter the resistivity measurement. The temperature correction, however, may be incorrect if surface conductivity contributes to the sample conductivity.

\section{Discussion}

Putting aside the discrepancy between LWD and laboratory resistivity measurements, relative resistivity variations are consistent. Both data sets indicate that there is probably an inverted correlation between the CEC and the sediment electrical conductivity in the interval around the Barbados décollement. This is an apparent paradox because an increase of the CEC should result in an increase of surface conductivity. However, this behavior can be understood from semiempirical models for electrical conductivity of shaly sands (Clavier et al., 1977; de Lima and Sharma, 1990; Sen and Goode, 1988; Waxman and Smits, 1968). All these models use the total CEC as a parameter and therefore assume, although not always explicitly, that surface conduction can be described in the same way in smectite interlayer spaces and on the external surfaces of the clay particles. The overall correlation observed between CEC and conductivity supports this assumption. It should be noted that although the Barbados sam- 
Table 5. Electrical conductivity measurements on whole-round samples.

\begin{tabular}{|c|c|c|c|c|c|c|c|c|c|c|c|c|c|c|c|c|}
\hline \multirow{2}{*}{$\begin{array}{l}\text { Core, section, } \\
\text { interval }(\mathrm{cm})\end{array}$} & \multirow[b]{2}{*}{$\mathrm{V} / \mathrm{H}$} & \multirow[b]{2}{*}{ Unit } & \multicolumn{4}{|c|}{$\begin{array}{l}\text { Normalized mineral abundance } \\
\text { from shipboard XRD (wt } \% \text { ) }\end{array}$} & \multicolumn{2}{|c|}{$\begin{array}{l}\text { Porosity } \\
(\%)\end{array}$} & \multicolumn{4}{|c|}{$\begin{array}{c}\text { Conductivity }(\mathrm{S} / \mathrm{m}) \\
\text { at frequency }\end{array}$} & \multicolumn{4}{|c|}{$\begin{array}{c}\text { Apparent formation factor } \\
\text { at frequency }\end{array}$} \\
\hline & & & Clay & Qtz. & Plag. & Calc. & Uncorrected & Corrected & $1 \mathrm{kHz}$ & $10 \mathrm{kHz} 1$ & $00 \mathrm{kH}$ & $1 \mathrm{MHz}$ & $1 \mathrm{kHz}$ & $10 \mathrm{kH}_{2}$ & $00 \mathrm{kHz}$ & $\mathrm{MHz}$ \\
\hline \multicolumn{17}{|l|}{$156-948 \mathrm{C}$} \\
\hline $7 \mathrm{X}-6,63-74 \mathrm{a}$ & $\mathrm{H}$ & IIc & 57.0 & 27.7 & 15.3 & 0.0 & 66.0 & 39 & 0.71 & 0.78 & 0.82 & 0.80 & 6.7 & 6.0 & 5.7 & 5.9 \\
\hline $15 X-6,55-61$ & $\mathrm{~V}$ & IIIb & 53.6 & 29.1 & 0.0 & 17.3 & 44.9 & 37 & 0.49 & 0.49 & 0.49 & & 9.5 & 9.5 & 9.6 & \\
\hline $15 X-6,103-109$ & $\mathrm{~V}$ & IIIb & 62.3 & 37.7 & TR & 0.0 & 49.9 & 39 & 0.51 & 052 & 0.53 & 0.53 & 9.3 & 9.1 & 8.9 & 8.9 \\
\hline $18 \mathrm{X}-5,139-150$ & $\mathrm{H}$ & IIIb & 57.8 & 19.5 & 2.3 & 20.4 & 47.5 & 40 & 0.87 & 0.88 & 0.90 & 0.88 & 5.4 & 5.3 & 5.2 & 5.4 \\
\hline \multicolumn{17}{|l|}{ 156-949B } \\
\hline \multirow[t]{2}{*}{$7 X-3,14-25$} & V & IIb & 53.0 & 25.0 & 3.6 & 18.4 & 55.4 & 43 & 0.83 & 0.87 & 0.91 & 0.89 & 5.6 & 5.4 & 5.2 & 5.3 \\
\hline & $\mathrm{H}$ & & & & & & 55.8 & 42 & 0.90 & 090 & 0.92 & 0.89 & 5.2 & 5.2 & 5.1 & 5.3 \\
\hline $15 \mathrm{X}-5,65-76 \mathrm{a}$ & $\mathrm{H}$ & IIc & 62.1 & 30.4 & 7.6 & 0.0 & 68.7 & 49 & 0.69 & 0.84 & 0.79 & & 6.8 & 5.6 & 5.9 & \\
\hline \multirow[t]{2}{*}{$25 \mathrm{H}-2,139-150$} & $\mathrm{H}$ & III & & & & & 55.7 & 37 & 0.96 & 1.06 & 1.12 & 1.12 & 4.9 & 4.4 & 4.2 & 4.2 \\
\hline & V & & & & & & 53.6 & 39 & 0.95 & 099 & 1.01 & 0.97 & 4.9 & 4.8 & 4.7 & 4.9 \\
\hline
\end{tabular}

Notes: $\mathrm{V}=$ vertical, $\mathrm{H}=$ horizontal. $\mathrm{TR}=$ trace. Assumed fluid conductivity $=4.7 \mathrm{~S} / \mathrm{m}$.

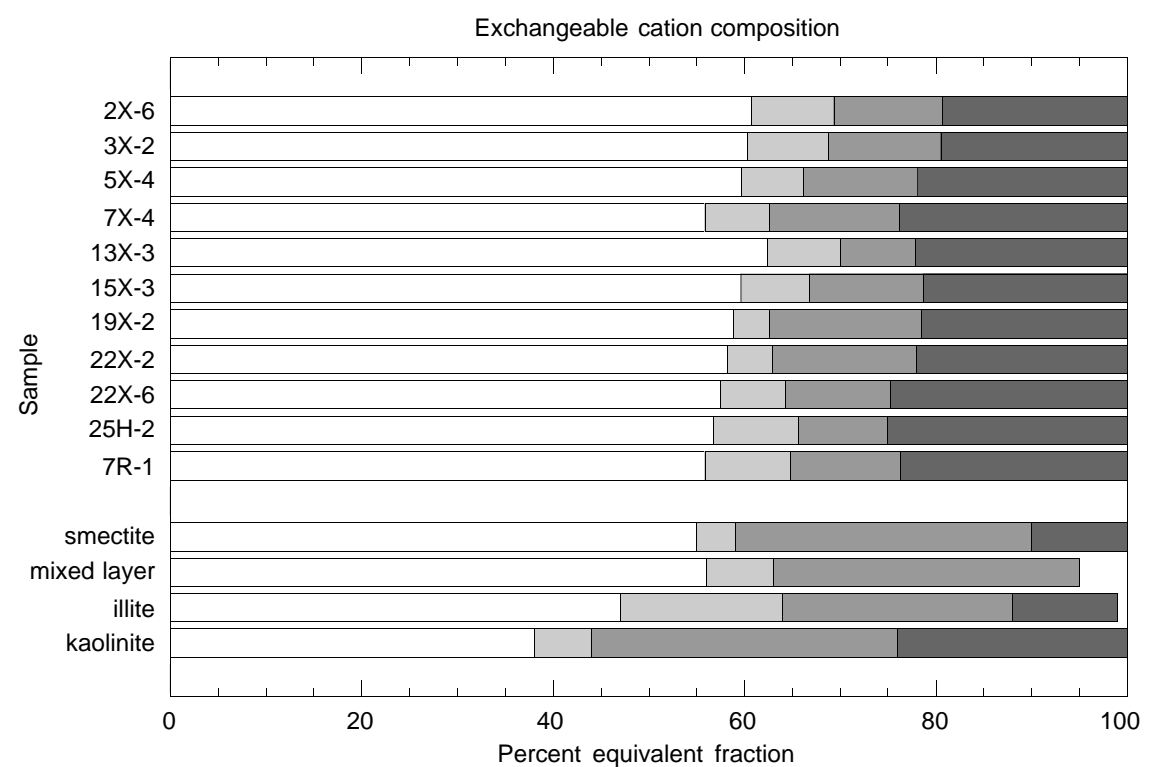

Figure 5. Exchangeable cation composition in percent of total charge (Site 949).

\begin{tabular}{llllll|}
\hline$\square$ & $\mathrm{Ca}$ & $\mathrm{Mg}$ & $\square$ & $\mathrm{K}$ & $\square \quad \mathrm{Na}$ \\
\hline
\end{tabular}

ples have a higher clay content than the samples to which these models were applied, the range of cation exchange capacity per unit fluid volume, $Q_{v},\left(Q_{v}=[\mathrm{CEC}] \times \rho_{g}[1-\varphi] / \varphi\right)$ is similar because of the higher porosity of the Barbados samples (Table 1). In the high salinity domain (i.e., when most counter-ions are confined in the Helmholtz layer), an asymptotic effective conductivity of the surface-conducting layer can be defined as the ratio of surface conductance to its thickness (about $0.6 \mathrm{~nm}$, as discussed earlier). For a $\mathrm{NaCl}$ solution, a value of about $6 \mathrm{~S} / \mathrm{m}$ at $20^{\circ} \mathrm{C}$, compatible with experiments on montmorillonite gels, is obtained (Clavier et al., 1977; de Lima and Sharma, 1990). As this value is only slightly higher than that of seawater at the same temperature $(4.8 \mathrm{~S} / \mathrm{m})$, the effect of surface conduction is expected to be moderate. On the other hand, the tortuosity increases very sharply with CEC (Clavier et al., 1977; Sen and Goode, 1988; Waxman and Smits, 1968), so that the net effect may be a decrease of conductivity, and decreasing conductivities with increasing CEC are indeed documented for a high-salinity pore fluid (Manheim and Waterman, 1974).

A large part of the variation of the tortuosity with CEC can be modeled by taking into account the increase of the volume of bound water with the CEC (Clavier et al., 1977; Sen and Goode, 1988). An effective porosity is then defined as

$$
\varphi_{e f f}=\varphi-v_{Q}(1-\varphi) \rho_{g} \times(\mathrm{CEC})
$$

where $\varphi$ is the total porosity, and $v_{Q}$ is the water volume per surface charge. To illustrate the consequences of variations of the CEC and of the amount of bound water, conductivities computed with Equation 10 from Sen and Goode (1977),

$$
\frac{\sigma}{\sigma_{0}}=\varphi_{\text {eff }}^{m}\left(1+\frac{m 1.93 Q_{v}}{\sigma_{0}}\right)+1.3 \varphi^{m} \frac{Q_{v}}{\sigma_{0}},
$$

are compared with LWD measurements (Fig. 13). $\sigma$ is the bulk sediment conductivity, $\sigma_{0}$ is the pore-fluid conductivity, and other parameters are already defined. CEC is made to vary from $0.3 \mathrm{eq} / \mathrm{kg}$, typical of lithological Unit III, to $0.6 \mathrm{eq} / \mathrm{kg}$, which is considered representative of Unit II, to $1 \mathrm{eq} / \mathrm{kg}$, which is the maximum value measured. Cases with different values of exponent $m$ and of the specific absorbed water volume $v_{Q}$ are considered. If $v_{Q}=0, m$ must be more 
than 4, and the conductivity increases as a function of the CEC (Fig. 13A). Such a high value of $m$ is physically unrealistic, even for a sediment composed of platelets of high aspect ratio (Jackson et al., 1978). Assuming $v_{Q}=0.28 \mathrm{l} / \mathrm{eq}$ (Clavier et al., 1977; Sen and Goode, 1988), which corresponds roughly to the two water layer case, conductivity appears to depend little on the CEC (Fig. 13B), and the main trend is fit with $m=2.7 . v_{Q}=0.40 \mathrm{l} / \mathrm{eq}$ corresponds roughly to the three water layer case and is an upper bound for the estimated chloride-free water content of most of the samples (22 water moles per eq). In this case, $m$ is of the order of 2, and a trend of increasing resistivity with CEC is obtained (Fig. 13C).

Laboratory measurements on the smectite-rich samples with the highest porosities $(>60 \%)$ cannot be fit by the models with any reasonable value of $m$ and $v_{Q}\left(m<3\right.$ and $v_{Q}<0.451 /$ eq). However, the model assumption that all exchangeable cations participate equally to surface conduction may be wrong when most of the exchangeable cations are interlayer cations. Smectite interlayer cations are mobile, and therefore should participate in the conduction, but their mobility is not known for the interlayer spacings usually found in sediments $(0.6$ or $0.9 \mathrm{~nm})$. Furthermore, model surface conductance is derived from measurements in $\mathrm{NaCl}$ solutions, and the influence of having a higher divalent cation content ( $40 \%$ of the total charge) in the boundary layers and/or interlayers is not known. An alternative explanation is to assume a high tortuosity for the network of conductive surfaces (Revil et al., 1996)

\section{CONCLUSION}

Because of the correlation between total water content in the sediment and CEC, which essentially reflects smectite content, quantitative interpretation of porosity logs in term of pore pressure may be biased. The proportion of water adsorbed on particle surfaces and in smectite interlayers varies from $1 / 6$ to more than $1 / 3$ in Barbados samples. This water is included in the routine porosity measurements and in the porosity computed from density logs and may obscure the "true" porosity trends. Although there is little doubt that the whole formation is undercompacted, a correlation of oedometer tests with other relevant physical properties, such as CEC, are needed to define a more precise porosity-effective pressure relationship.

Electrical conductivity measurements also show the influence of clay mineralogy. The conductivity at a given water content tends to decrease with CEC, for CEC > $0.30 \mathrm{eq} / \mathrm{kg}$. For a pore-fluid conductivity comparable to that of seawater, this behavior may be explained if the increase in surface conductivity is more than balanced by the loss of "true" pore space as water is adsorbed in smectite interlayers. The particularly high resistivity of some of the samples leads to wonder whether the conductance of the smectite interlayers is equal or smaller than the conductance of the external double layers described by physical models.

Additionally, determination of bound water content is of interest to establish the chloride budget of the wedge, and measurements of electrical conductivity have implications for the modeling of the migration of chemical elements, as electrical conductivity can be related to ion diffusivity (Iversen and Jørgensen, 1993; Manheim and Waterman, 1974; McDuff and Ellis, 1979).

\section{ACKNOWLEDGEMENTS}

I am grateful to D. Tessier of INRA (Versailles) for his help throughout the project and to L. Jouniaux, J.P. Pozzi, and G. Marolleau who made the resistivity measurements possible. This study initiated from discussions on board the JOIDES Resolution, and proceeded with more discussions. I wish to thank all who participated, notably: P. Blum, W. Brückmann, M. Kastner, M. Underwood, J.C.
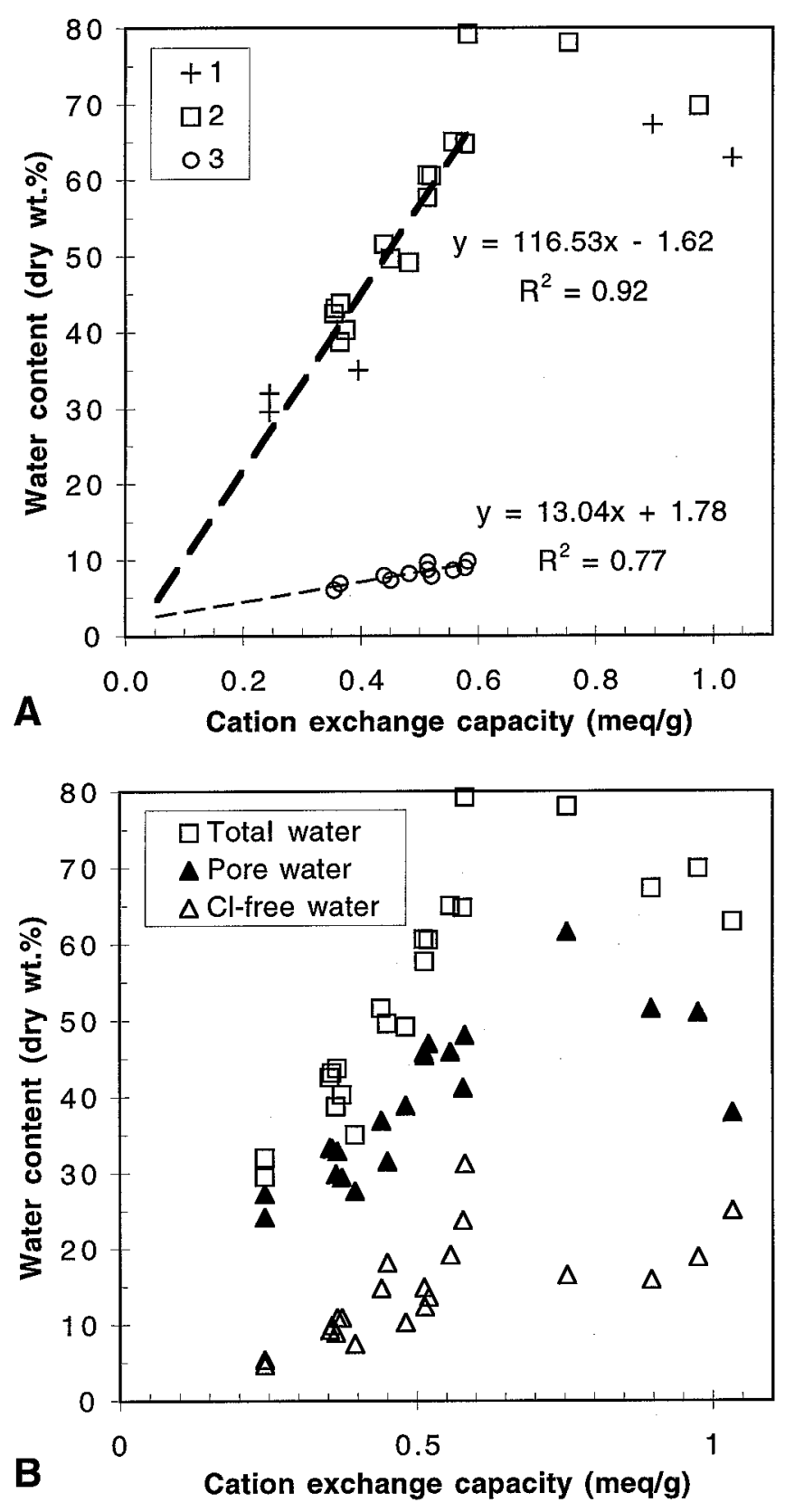

Figure 6. A. Water contents (dry wt $\%$ ) as a function of cobaltihexamine cation exchange capacity. 1 = total water content at Site 948 (whole-round samples); 2 = total water content at Site 949 (all samples); and 3 = water retained after air drying, determined by heating to $200^{\circ} \mathrm{C}$. B. Distribution of water content between pore water (water of same chlorinity as interstitial water extract) and chloride-free water (interlayer and double layer water).

Moore, A. Rabaute, K. Moran, P. Pézard, R. Prost, B. Velde, and A. Bauer. Most chemical determinations were done at INRA (Arras) in the laboratory of H. Ciesielski, ATD by M. Herviot (INRA, Versailles), and complementary analyses were done by N. Catel at ENS. I thank J.V. Roberts and P. Pézard for their constructive reviews. This work was supported by CNRS-INSU through the Geosciences Marines fund. 


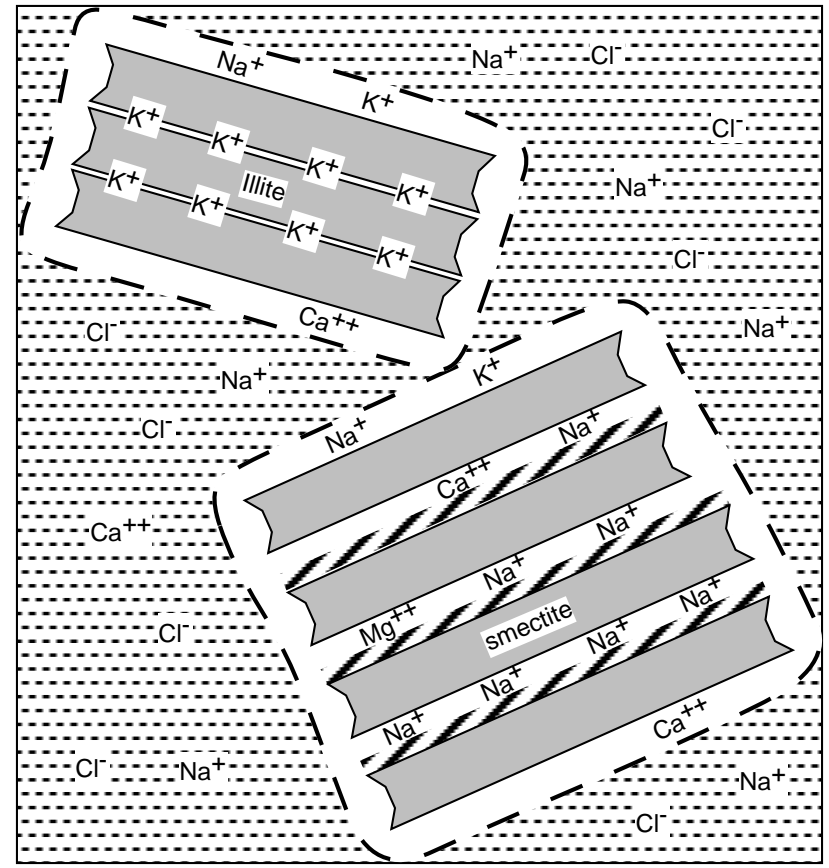

\section{$\overline{1 \mathrm{~nm}} \quad \because \because Z-Z \quad$ Chloride bearing pore water \\ ( Chloride free water: \\ - double layer and interlayer water \\ 2. Water retained after air drying}

Figure 7. Schematic representation of the water and ion distribution in a clay sample. The 1-nm scale applies to the thickness of the clay layers, the interlayers, and the layer of chloride exclusion around the particles (double layer), but the clay particles are not to scale. The ions represented in the pore space and at the exchangeable sites follow the same proportions as that determined on the samples. Water is schematically divided between the pore water, which contains chloride ions, and the interlayer and double layer water, that does not contain chloride. Part of the interlayer water is retained after air drying at room temperature. The surface conduction corresponds to conduction in the double layer and presumably also in the interlayer spaces. In illites, all the exchangeable cations are adsorbed on the external surfaces of the particle. In smectites, only a small fraction of the exchangeable cations are in the double layers, most are in the hydrated interlayers.

\section{REFERENCES}

Archie, G.E., 1942. The electrical resistivity $\log$ as an aid in determining some reservoir characteristics, J. Pet. Technol., 5:1-8.

Bangs, N.L.B., Westbrook, G.K., Ladd, J.W., and Buhl, P., 1990. Seismic velocities from the Barbados Ridge Complex: indicators of high porefluid pressures in an accretionary complex. J. Geophys. Res., 95:87678782

Bird, P., 1984. Hydration-phase diagrams and friction of montmorillonite under laboratory and geologic conditions, with implications for shale compaction, slope stability and strength of fault gouge. Tectonophysics, 107:235-260.

Blum, P., 1994. Index properties, vers. 155. In ODP Shipboard laboratory Manual, College Station, TX (Ocean drilling Program).

Bray, C.J., and Karig, D.E., 1985. Porosity of sediments in accretionary prisms and some implications for dewatering processes. J. Geophys. Res., 90:768-778.

Bruand, A., and Prost, R., 1987. Effect of water content on the fabric of a soil material: an experimental approach. J. Soil Sci., 38:461-472.

Clavier, C., Coates, G., and Dumanoir, J., 1977. The theoretical and experimental basis for the "dual-water" model for the interpretation of shaly sands. Soc. Pet. Eng. Pap., 6859
Colten-Bradley, V.A., 1987. Role of pressure in smectite dehydration effects on geopressure and smectite-to-illite transformation. AAPG Bull., 71:1414-1427.

de Lima, O.A.L., and Sharma, M., 1990. A grain conductivity approach to shaly sandstones. Geophysics, 55:1347-1356.

de Lima, O.A.L., and Sharma, M.M., 1992. a generalized Maxwell-Wager theory for membrane polarization in shay sand. Geophysics, 57:431-440.

Grim, R.E., 1953. Clay mineralogy. New-York (McGraw-Hill).

Iversen, N., and Jørgensen, B.B., 1993. Diffusion coefficients of sulfate and methane in marine sediments: Influence of porosity. Geochim. Cosmochim. Acta, 57:571-578.

Jackson, P.D., Taylor Smith, D., and Stanford, P.N., 1978. Resistivity-porosity-particle shape relationships for marine sands. Geophysics, 43:12501268.

Keren, R., and Shainberg, I., 1975. Water vapor isotherms and heat of immersion of $\mathrm{Na} / \mathrm{Ca}$ montmorillonite systems - I: Homoionic clay. Clays Clay Miner., 23:193-200.

Manheim, F.T., and Waterman, L.S., 1974. Diffusimetry (diffusion constant estimation) on sediment cores by resistivity probe. In von der Borch, C.C., Sclater, J.G., et al., Init. Rep. DSDP, 22: Washington, D.C. (U.S. Govt. Printing Office), 663-670.

McDuff, R.E., and Ellis, R.A., 1979. Determining diffusion coefficients in marine sediments: a laboratory study of the validity of resistivity techniques. Am. J. Sci., 279:666-675.

Meade, R.H., 1964. Removal of water and rearrangement of particles during the compaction of clayey sediments-review. U.S.G.S. Prof. Pap.: 497B: Washington, D.C. (U.S. Gov. Printing office).

Monnier, G., Stengel, P., and Fies, J.C., 1973. Une méthode de mesure de la densité apparente de petits agglomérats terreux. Application à l'analyse des systèmes de porosité du sol. Annales Agronomiques, 24:533-545.

Moore, J.C., Shipley, T.H., Goldberg, D., Ogawa, Y., Filice, F., Fisher, A., Jurado, M.-J., Moore, G.F., Rabaute, A., Yin, H., Zwart, G., Brückmann, W., Henry, P., Ashi, J., Blum, P., Meyer, A., Housen, B., Kastner, M., Labaume, P., Laier, T., Leitch, E.C., Maltman, A.J., Peacock, S., Steiger, T.H., Tobin, H. J., Underwood, M.B., Xu, Y., and Zheng, Y., 1995. Abnormal fluid pressures and fault-zone dilation in the Barbados accretionary prism: Evidence from logging while drilling. Geology, 23:605608.

Murthy, A.S.P. and Ferrell, R.E. Jr., 1972. Comparative chemical composition of sediment interstitial waters. Clay Clay Miner., 20: 317-321.

Olhoeft, G.R., 1981. Electrical properties of rocks. In Touloukian, Y.S., Judd, W.R., and Roy, R.F., Physical Properties of Rocks and Minerals: New York, NY (McGraw-Hill), 257-330.

Orsini, L., and Remy, J.-C., 1976. Utilisation du chlorure de cobaltihexamine pour la determination simultanee de la capacite d'echange et des bases echangeables des sols. Science du Sol, 4:269-275.

Pezard, P.A., 1990. Electrical properties of mid-ocean ridge basalt and implications for the structure of the upper oceanic crust in hole 504B. J. Geophys. Res., 95:9237-9264.

Pride, S., 1994. Governing equations for the coupled electromagnetics and accoustics of porous media. Phys. Rev. B, 50:15678-15696.

Ransom, B., and Helgeson, H.C., 1995. A chemical and thermodynamic model of dioctahedral 2:1 layer clay minerals in diagenetic processes: The dehydration of smectite as a function of temperature and depth in sedimentary basins. Am. J. Sci., 295:245-281.

Revil, A. and Glover, P.W.J., 1997. Theory of ionic surface electrical conduction in porous media. Phys. Rev., B., 55:1757-1772.

Revil, A., Darot, M., Pezard, P.A., and Becker, K., 1996. Electrical conduction in oceanic dikes, Hole 504B. In Alt, J.C., Kinoshita, H., Stokking, L.B., and Michael, P.J. (Eds.), Proc. ODP, Sci. Results, 148: College Station, TX (Ocean Drilling Program), 297-305.

Sayles, F.L., and Mangelsdorf, P.C., 1977. The equilibration of clay minerals with seawater: exchange reactions. Geochim. Cosmochim. Acta, 41:951960.

Sen, P.N., and Goode, P.A., 1988. Shaly sand conductivity at low and high salinities. An. Symp. Soc. Prof. Well Log Analysts, 29.

Shi, Y., and Wang, C.-Y., 1988. Generation of high pore pressures in accretionary prisms: Inferences from the Barbados Subduction Complex. $J$. Geophys. Res., 93:8893-8909.

Shipboard Scientific Party, 1995. Explanatory notes. In Shipley, T.H., Ogawa, Y., Blum, P., et al., Proc. ODP, Init. Repts., 156: College Station, TX (Ocean Drilling Program), 39-68.

Shipley, T.H., Ogawa, Y., Blum, P., et al., 1995. Proc. ODP, Init. Repts., 156 College Station, TX (Ocean Drilling Program). 
Taylor, E., and Leonard, J., 1990. Sediment consolidation and permeability at the Barbados Forearc. In Moore, J.C., Mascle, A., and, et al., Proc. ODP, Sci. Results, 110: College Station, TX (Ocean Drilling Program), 289308.

Tessier, D., 1991. Behaviour and microstructure of clay minerals. In De Boodt, M., Hayes, M. and Herbillon, A., Soil colloids and their associations in aggregates: (Plenum), 387-413.

Tribble, J.S., 1990. Clay diagenesis in the Barbados Accretionary complex: Potential impact on hydrology and subduction dynamics. In Moore, J.C., Mascle, A., et al., Proc. ODP, Sci. Results, 110: College Station, TX (Ocean Drilling Program), 97-110.

Von Herzen, R.P., Francis, T.J.G., and Becker, K., 1983. In situ large scale electrical resistivity of the ocean crust, Hole 504B. In Cann, J.R., Langseth, M.G., Honnorez, J., Von Herzen, R.P., White, S.M., et al., Init. Rep. DSDP, 69: Washington, D.C. (U.S. Govt. Printing Office), 237-244.
Waxman, M.H., and Smits, L.J.M., 1968. Electrical conductivities in oilbearing shaly sands. Soc. Pet. Eng. J., 8:107-122.

Date of initial receipt: 12 February 1996

Date of acceptance: 22 November 1996

Ms 156SR-020
Figure 8. Water adsorption per counter-ion charge for pore-water saturated samples and air dried samples (see text). Adsorbed water content is the chloride-free water as in Figure 6. Counter-ion charge is assumed equal to cobaltihexamine CEC.

Figure 9. Temperature-corrected LWD phase resistivity vs. porosity computed from LWD gamma densitometry. Symbols 1, 2, 3, and 4 refer to zones 1, 2, 3, and 4, as defined in the text.
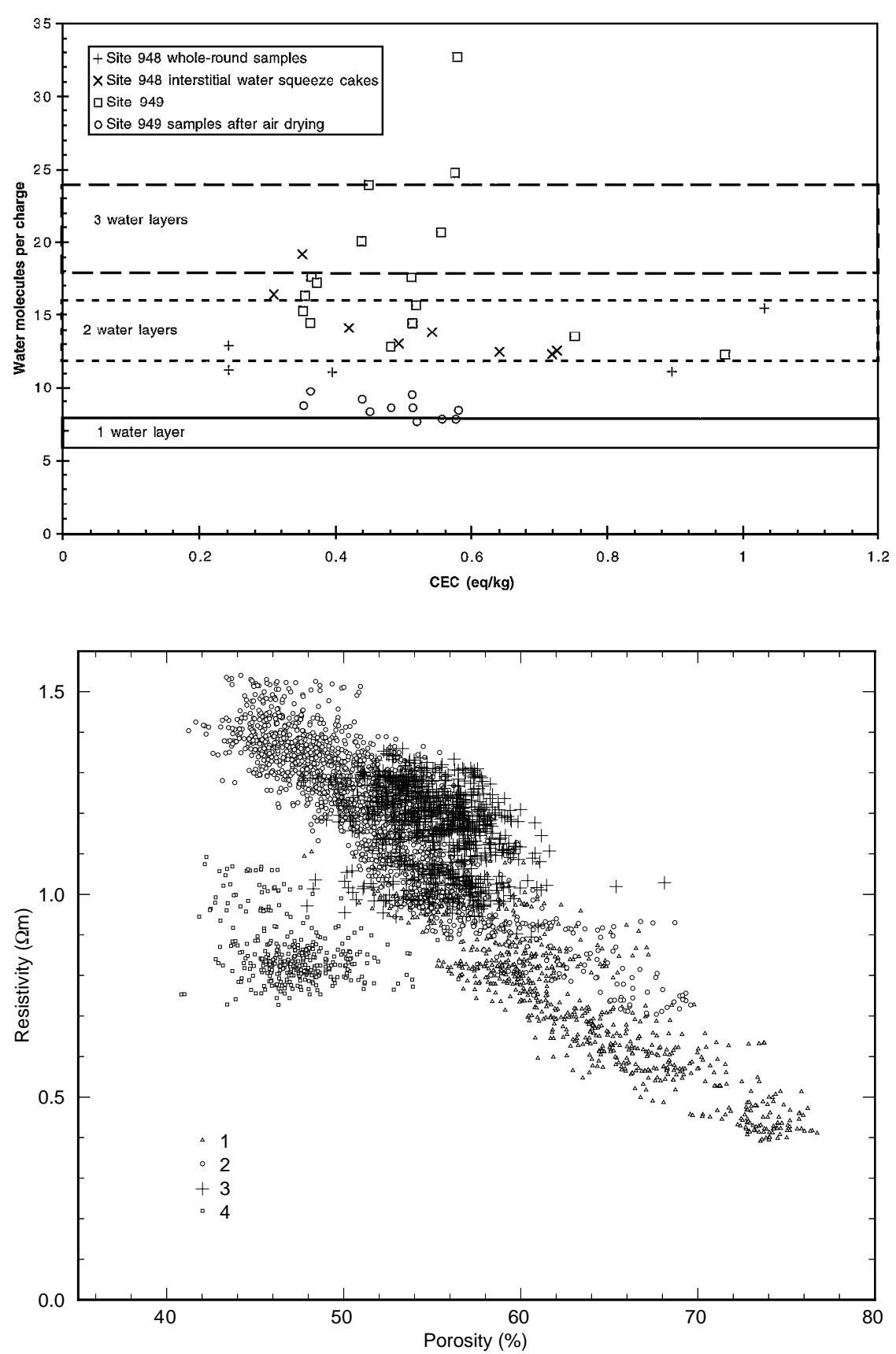
Hole 948A LWD

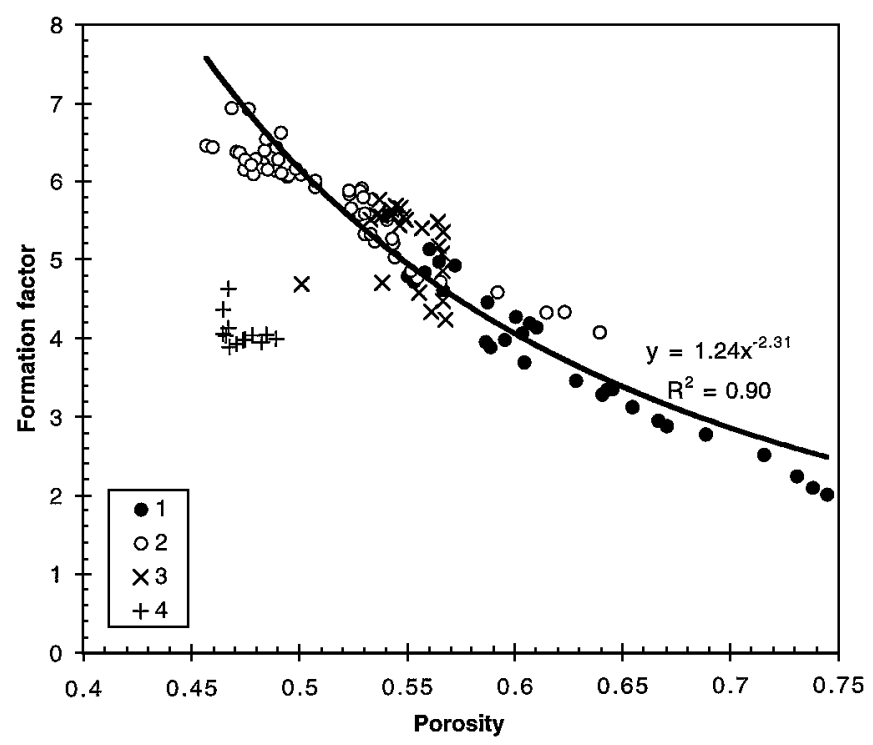

Figure 10. Temperature- and salinity-corrected apparent formation factor from LWD, vs. porosity from LWD gamma densitometry. Symbols 1, 2, 3, and 4 refer to zones $1,2,3$, and 4 , as defined in the text.

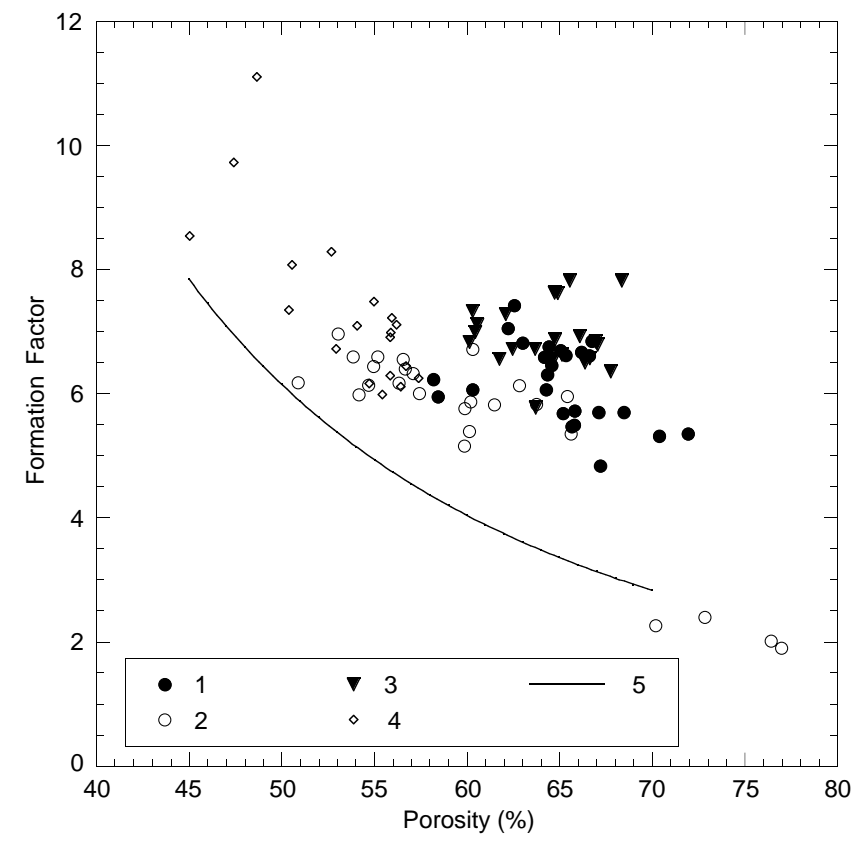

Figure 11. Apparent formation factor measured on board at $40 \mathrm{kHz}$ on cores from Holes 949B and 949D. 1 = 255.4-291.9 mbsf (lithologic Unit IIc); 2 = 0-255.4 mbsf and 302.1-352 mbsf (calcareous lithologies, lithologic Units I and IIb); 3 = 352-404 mbsf (lithologic Units IIc and IIe); $4=327.5 \mathrm{mbsf}$ and below (base lithologic Unit IIa and lithologic Unit III); and $5=$ trend from LWD (Fig. 10). Note the cluster of points of anomalously high resistivity.

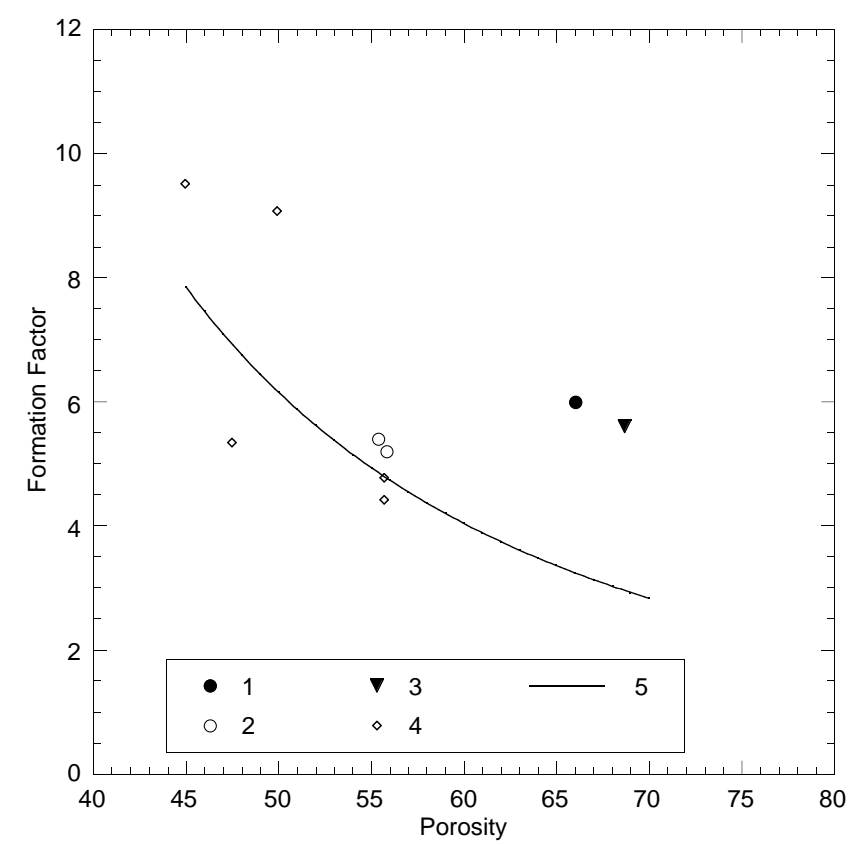

Figure 12. Apparent formation factor measured in the shore-based laboratory, at $10 \mathrm{kHz} .1=$ interval $156-948 \mathrm{C}-7 \mathrm{X}-6,63-74 \mathrm{~cm}$, from lithologic Unit IIc; 2 = interval 156-949B-7X-3, 14-25 cm, claystone with nannofossils from lithologic Unit IIb; 3 = interval 156-949B-15X-5, 65-76 cm, from lithologic Unit IIc; 4 = all samples from lithologic Unit III; and $5=$ trend from LWD (Fig. 10). 


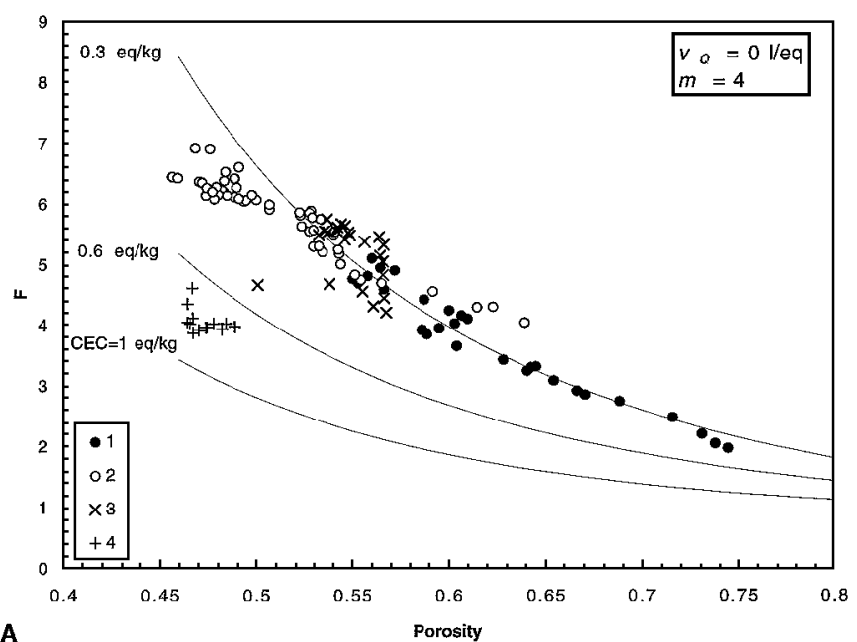

A
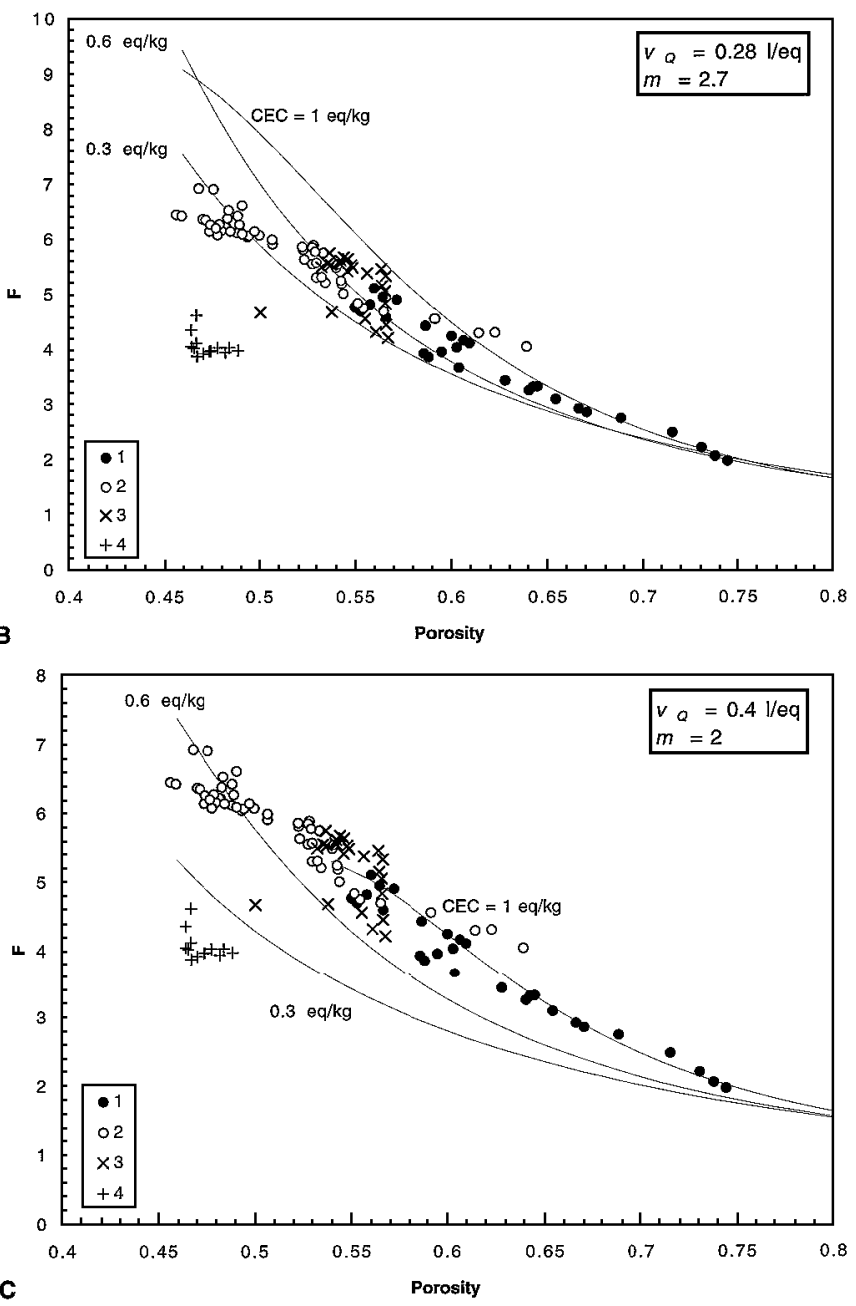

Figure 13. A-C. Comparison of LWD data with electrical conductivity models including a surface conductivity term (Sen and Goode, 1988). Symbols 1, 2,3 , and 4 correspond to zones $1,2,3$, and 4 , which are defined in the text. 